\title{
NATURAL AND HUMAN-INDUCED LAND DEGRADATION AND ITS IMPACT USING GEOSPATIAL APPROACH IN THE KALLAR WATERSHED OF TAMIL NADU, INDIA
}

\author{
Abdul Rahaman S. ${ }^{1 *}$, Aruchamy Solavagounder ${ }^{1}$ \\ 'Department of Geography, School of Earth Science, Bharathidasan University, Tiruchirappalli - 620024 Tamil Nadu, \\ India \\ *Corresponding author: abdulatgeo@gmail.com \\ Received: June 1st, 2020 / Accepted: November 20th 2020 / Published: December 31 ${ }^{\text {st }}, 2020$ \\ https://DOl-10.24057/2071-9388-2020-105
}

\begin{abstract}
Land degradation is human-induced and natural process that adversely affects the land, to function effectively within a complex ecosystem. In recent years, the Kallar watershed has encountered various kinds of multifarious problems on both land and water in the urban and its environs. The upper part of the study area is facing water scarcity problems in the past few years, but which included no such rare occurrences in the past. The mid-portion in the vicinity of foothills are highly affected by soil erosion, whereas the lower portion of the area has faced problems like land degradation, such as an unusual increase of wastelands and conversion of good agriculture lands into construction plots. Apart from these, the study area is frequently affected by nature induced disasters like a landslide, forest fire, flooding, and drought. In this complex situation, the qualitative assessment of human-induced land degradation and its impact is essential. For this, Geospatialbased Multi-Criteria Evaluation (MCE) as a multidisciplinary approach has been adopted. To assess land degradation, six major criterions are preferred such as terrain (slope, elevation), environment (landuse/land cover, NDVI), soil erosion, and demography (population density). Considerable weights and ranks were assigned through an empirical MCE method. Based on the criteria, the land degradation was carefully delineated into five significant categories such as low (38.3\%), moderately (23.6\%), marginally (15.4\%), highly (4.8\%), and severely degraded (17.8\%). The depletion of vegetation cover on hilly terrain and subsequent cultivation without proper protection measures constitute the possible reason for severe soil erosion and land degradation.
\end{abstract}

KEY WORDS: Land Degradation, Soil Erosion, Analytical Hierarchy Process, Sustainability

CITATION: Abdul Rahaman S., Aruchamy Solavagounder (2020). Natural And Human-Induced Land Degradation And Its Impact Using Geospatial Approach In The Kallar Watershed Of Tamil Nadu, India. Geography, Environment, Sustainability, Vol.13, No 4, p. 159-175 https://DOI-10.24057/2071-9388-2020-105

ACKNOWLEDGMENT: I would like to acknowledge the UGC - Basic Science Research Fellowship scheme for aiding me to carry out my research work. Also, thank the UGS-SAP-DRS I \& II project scheme of Department of Geography, Bharathidasan University for providing high-resolution IRS LISS IV data products for the analysis. I am grateful to SAA, KAR, Meena Gopi, and MJ for their support in the editing of the manuscript.

Conflict of interests: The authors reported no potential conflict of interest.

\section{INTRODUCTION}

Globally, land degradation predominantly occurring in the arid, semi-arid, and dry sub-humid regions (UNCCD 1999; IPCC 2001) due to unstable climatic conditions and human activities which invariably causes severe ecological and socio-economic issues in the current scenario (Omar et al. 2013). It critically involves two complex systems: the natural ecosystem and the human social system (Barrow 1994; Scott and Conacher 2008). It implies the loss of productive potential, increasing unsustainability, and potential instability. The land experiences unfavourable impact on agricultural productivity and ecological function which ultimately affects human sustenance and essential quality of life (Taddese 2001; Eliasson et al. 2003; Masoudi 2014; Pan and Li 2013; Barzani and Khairulmaini 2013; Masoudi and Amiri 2015; Masoudi et al. 2018).
The key concept of land degradation «refers to the deterioration or total loss of the productive capacity of the fertile soils for present and future use» (FAO 1980). Such potential losses are due to various forms of soil erosion by different agents, along with chemical and physical deterioration. It involves two physical processes: soil erosivity (tending to cause erosion by the erosive agents such as wind and water) and soil erodability (susceptible to erosion) (Morgan 1983; Rahaman et al. 2015; Nitheshnirmal et al. 2019). Soil degradation is not only the interaction between physiochemical and biological factors but also includes soil properties, climatic factors and topography (Taguas et al. 2015; Brevik et al. 2015; Bhattacharyya 2015). Additionally, it includes human factors and landuse management practices (Khaledian et al. 2017; Camprubi et al. 2015; Cerda et al. 2016).

Sustainability obtains the substance for today's leading global framework for international cooperation. The 2030 Sustainable Development Agenda and it is Sustainable 
Development Goals (SDGs), has 17 SDGs. Each of the 17 SDGs includes specific targets to be achieved by 2030. The goals and targets are universal; it denotes, they apply to all countries around the world, not just to underprivileged countries (SDG guideline 2017). Present research broadly focuses on one of the important Sustainable Development Goals (SDGs) that is Life on Land (Goal 15). It refers to protect, restore and promote sustainable use of terrestrial ecosystems, sustainable forest management, combat desertification, and eradicate and minimise land degradation and biodiversity loss (UN 2015). The 15.1, 15.2 and 15.3 targets and global indicators of 15.2.1, and 15.3.1 have been considered and its details are given below.

Under international agreements (15.1) the objective is to ensure the conservation, restoration and sustainable use of forests, wetlands, mountains and drylands by 2020. It also includes effective implementation of sustainable management of all forests; halt deforestation, degraded forests, increase afforestation and reforestation globally (15.2). By 2030, combat desertification, restore degraded land and soil, including land affected by desertification, drought and floods, and strive to achieve a land degradation-neutral world (15.3).

The present study focuses on the above-mentioned SDG main targets of which the following two global indicators were addressed in detail with appropriate case studies such as (1) Progress towards sustainable forest management (15.2.1); (2) Proportion of land that is degraded over the total land area (15.3.1). Globally many organizations and scientific communities have intensively involved and concentrated on land degradation and desertification (UNCCD, IPCC, etc). Numerous independent, academic researchers from around the world are working extensively on monitoring land and environmental degradation (Naseer and Puneeta 2018; Xie 2020; Rahaman and Venkatesh 2020). Those studies were used individually and multi factors were used to assess and monitor land degradation. The assessment of land degradation represents a multifaceted process. It is not a single factor outcome; relatively, an integrated property of interacting human and biophysical factors (Svensson 2005; Masoud 2018; Venkatesh et al. 2020). These works address the role of human activity in land degradation and their influencing factors such as unplanned landuse practices, over utilisation of agricultural lands, conversion of agricultural land into settlement plots, inappropriate conservation methods, planning, land management, and tourism activities. From an ecological and socioeconomic perspective, the selection of appropriate factors such as vegetation, soil, climate, terrain, and demographic layers were evaluated. Within these thematic factors soil erosion, landuse/land cover, NDVI, slope, elevation, and population density were assessed in detail.

Empirical evaluation of soil erosion is one of the key factors in the land degradation assessment. In recent years, as a part of the environment and land degradation assessment policy for sustainable agriculture and development, soil erosion is recognised increasingly as a hazard, which is a serious issue in mountain areas (Millward and Mersey 1999; Angima et al. 2003; Jasrotia and Singh 2006; Dabral et al. 2008; Sharma 2010). Every year around the world 75 billion tons of soil is eroded from the earth's surface, which is about 13-40 times as fast as the natural rate of erosion (Zuazo et al. 2009). Asia has the highest soil erosion rate of 74 tons/acre/year, (El-Swaify 1997). In India, $45 \%$ (130 Mha) of the total geographic area is affected by severe soil erosion through ravines, gullies, shifting cultivation, sandy areas, cultivated wastelands, deserts, and waterlogging. The Kallar watershed has a maximum annual soil loss of $398.5 \mathrm{t} / \mathrm{h}^{-1} / \mathrm{y}^{-1}$ and $>100 \mathrm{ton} / \mathrm{h}^{-1} / \mathrm{y}^{-1}$ which is about $15 \%\left(200 \mathrm{~km}^{2}\right)$ of the geographic area (Abdul et al. 2015).

Land degradation eventually leads to enduring and apparent loss of vegetation cover, reduced biomass productivity over time and space (Prince et al. 2009; Jong et al. 2011; Nicholson 1998; Helldén 2008; MEA 2005), it can be detected by comparing actual vegetation levels with potential levels (Haboudane et al. 2002; Eisfelder et al. 2012; D'Odorico et al. 2013; Zhou et al. 2015). Among numerous vegetation indices, the Normalized Difference Vegetation Index (NDVI) (Lin et al. 2016; Wessels et al. 2006, Rahaman et al. 2017a) has demonstrated its reliability in monitoring land degradation. However, the declining NDVI range is associated with various natural factors, i.e. unpredicted rainfall, seasonal variation, and human activity (landuse). Change detection studies of LULC have proven to be effective in assessing the potential adverse impacts on the environment (Leh et al. 2013; Pankaj, et al. 2019; Rahaman et al. 2020). Through LULC Dynamics and simulation models, the extent of land degradation at the landscape level can be evaluated and effective strategies for land management can be developed (Gessesse et al. 2015; Rahaman et al. 2017a).

Abiotic ecological factors like terrain conditions and soil characteristics also influence land degradation in the mountain regions. Terrain conditions determine soil erosion hazards. In mountain areas terrain factors such as elevation and slope play a significant role in land degradation. The steep slope and high elevation mountain/hill lands are more prone to water-related soil erosion, which increases the severity of soil degradation (FAO 1990). Human interventions are highly dominant in low altitude and moderately slope areas, hence being a crucial factor for extensive deforestation in those areas. Increasing population growth combined with other factors causes extensive environmental deterioration on a large scale (FAO/RAPA 1990, p.10).

Currently, the UNCCD has not yet approved any recommended methodology to calculate these indicators mentioned in 15.1 \&15.2 (Olena Dubovyk 2017). Few agencies have tried to implement Land Degradation Neutrality based on Soil values and its landuse changes in Germany (Stephanie et al. 2018). The Geospatial based multi-criteria evaluation approach is widely used; it is an accepted model that assesses land degradation at various scales and it supports researchers and policymakers to take appropriate decisions. Remote sensing techniques have emerging technology in spatial information studies. The principles of repetitiveness and consistency, are the prerequisites for land degradation monitoring (Olena 2017). Remote Sensing technology provides significant information for integrated approaches to combining satellite data with specific tools, geographic information system (GIS) analysis, and modelling techniques (Röder et al. 2008). Analytical hierarchy process (AHP) is one of the multi-criteria decision analysis that is popularly utilised to make a decisions related to spatial issues. Several studies were conducted through geospatial techniques coupled with the AHP method i.e. landslides, prioritization of watersheds and many other spatial issues (Feizizadeh and Blaschke 2014; Abdul et al 2014; Rahaman et al. 2015, and 2017b; Ghorbanzadeh et al. 2017). It evaluates various multi-factors and helps to take appropriate decisions to achieve the target objectives.

Over the years, increasing population, growing industrialisation, expanding agricultural activity and rising 
living standards have increased land degradation and extensive deforestation in mountain areas, especially in the Kallar watershed. Limited studies were attempted in the aspects of desertification, biodiversity loss, etc. Due to this, there is a lack of natural and human-induced land degradation assessment in the mountainous terrain along with the semi-arid region. This research aims to assess natural and human-induced land degradation factors and their impact in the Kallar watershed. To achieve this aim, the following objectives were framed: Determination of land degradation criteria (physical, climatic, environmental and demographic). Integration of various factors to delineate the land degradation vulnerable zones using AHP and GIS within the watershed and to suggest appropriate land resource planning methods, effective management practices and conservation measures in these areas.

\section{DATA AND METHODOLOGY}

\section{Study Area}

Stretching from west to east, the Kallar watershed is situated in the Eastern part of the Western Ghats. Being a part of the Bhavani River basin, its main river sources are from Moyar and River Bhavani. Spatially located between $11^{\circ} 17^{\prime} 0^{\prime \prime}$ to $11^{\circ} 31^{\prime \prime} 0^{\prime \prime} \mathrm{N}$ Latitude and $76^{\circ} 39^{\prime} 0^{\prime \prime}$ to $77^{\circ} 8^{\prime}$ $45^{\prime \prime}$ E Longitude it covers an area of $1281.2 \mathrm{~km}^{2}$. It comprises of three districts: The Nilgiris, Coimbatore, and Erode, it includes 6 taluks (Coonoor, Kothagiri, Udhagamandalam, Mettupalayam, Coimbatore north, and Sathyamangalam); and 89 Revenue villages (Fig. 1). The maximum and minimum elevation encountered in the watershed is about $177 \mathrm{~m}$ and $2615 \mathrm{~m}$ above MSL. About 50\% of these areas are covered with mountains that have diverse plant communities. These diverse plan communities consist of various types of forest cover and agricultural activities, such as tea, coffee plantation, vegetables, and orchards, which are cultivated in the upper and the lower regions.
This region is salubrious experiences a temperate climate for more than half of the year. The average day temperature of the watershed is $20.15^{\circ} \mathrm{C}$ to $30^{\circ} \mathrm{C}$ and the average rainfall is about $>1400 \mathrm{~mm}$. The winter is relatively cool. The maximum rainfall is received during October and November. The Kallar streams flow from the Southwest to the north-eastern region of the Western Ghats. Being built-in the north-eastern part of the watershed, the Bhavanisagar dam serves as the primary source of irrigation and hydroelectric power generation. This area is covered by clayey soil, loam soil, and rock outcrop on steep to narrow slope landform. Geomorphologically, the watershed is characterised by steep structural hills, denudational hills, narrow gorges, and intermountain valleys. Geologically, charnockite, and fissile hornblende-biotite gneiss covers a major portion of the study area.

\section{DATA}

The assessment of land degradation is influenced by multiple factors that were collected and extracted from different data sources. In this study, baseline layers were generated from the Survey of India (SOI) toposheets $58 \mathrm{~A} / 11,15,16$ and $58 \mathrm{E} / 3$ \& 4 at the scale of $1: 50,000$. The Landsat 8 Operational Land Imager (OLI) data were downloaded from the United States Geological Survey (USGS) Global Visualization Viewer (GloVis) web portal (https://glovis.usgs.gov). Applied pre-processing techniques like atmospheric and radiometric corrections were calibrated for post-processing. Landsat 8 images for the years of 2012 and 2015 with the spatial resolution of $30 \mathrm{~m}$ were used to generate two important factors such as NDVI and landuse land cover. IRS - Linear Imaging SelfScanning Sensor-4 (LISS IV) data product in the year of 2015 with the spatial resolution of $5.8 \mathrm{~m}$ was used to classify various landuse classes by manual digitization method and was compared with the existing and present condition of landuse / land cover. Comparisons with the generated

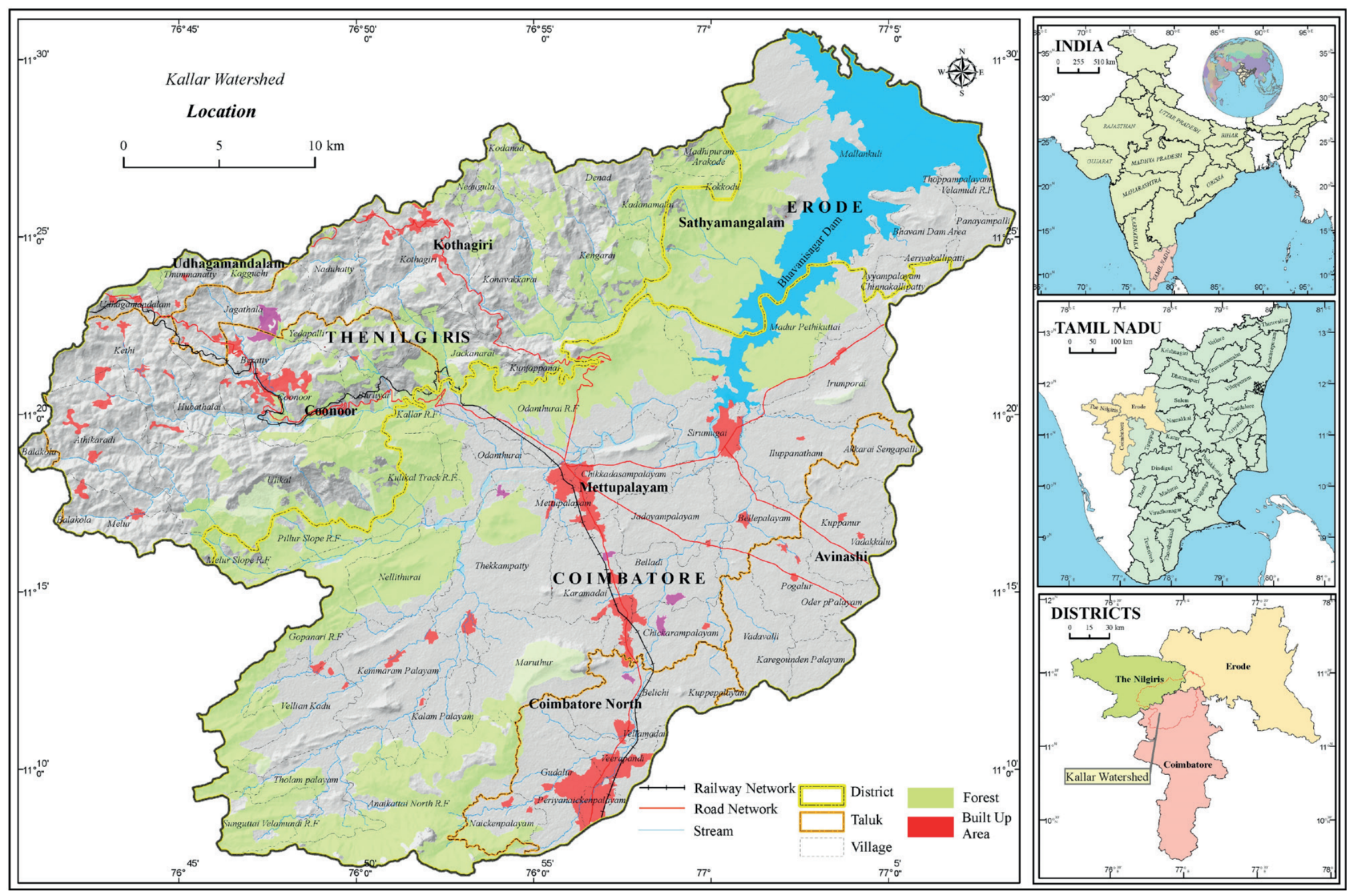

Fig. 1. Study Area 
vulnerable land degraded zones were formulated. Advanced Spaceborne Thermal Emission and Reflection Radiometer (ASTER) Global Digital Elevation Model (DEM) data has a spatial resolution of $30 \mathrm{~m}$ was used to derive slope and elevation maps. About 30 years of daily precipitation data (1982-2012), from the Indian Meteorological Department (IMD), was used to derive rainfall erosivity and understand the general rainfall pattern of the Kallar watershed. Another important dataset used are soil parameters (physical and chemical properties of the soil) which were collected from Tamil Nadu Agricultural University. The data was used to calculate soil erodibility. The working scale of geographic maps was chosen at 1:50,000. Arc GIS 10.1 and Erdas 9.2 software products were used to prepare thematic maps and layouts.

\section{METHODOLOGY}

\section{Revised Universal Soil Loss Equation (RUSLE)}

RUSLE is a science-based tool; used to calculate potential average annual soil loss (A) has been improved over the last several years. It is widely used for site evaluation, planning purposes and formulate erosion control measures. It estimates the severity of erosion. Erosion is a function of erosivity and erodibility (Morgan 1983). The power of erosion agent to erode is designated as the erosivity (raindrop impact and surface runoff) and the susceptibility (inverse of resistance) of the soil to erosion is its erodibility. RUSLE factors contain both erosivity and erodibility effect. Erosivity - RKLSCP, Erodibility - RKLS.

The RUSLE model calculates potential average annual soil loss (A) which is given below:

$$
A=R \times K \times L S \times C \times P
$$

Where $A$ represents computed spatial average annual soil loss, on a yearly basis (t/ ha- $\left.\mathrm{h}^{-1} / \mathrm{y}^{-1}\right)$; $\mathrm{R}$ is the rainfall-runoff erosivity factor $\left(\mathrm{MJ} \mathrm{mm} / \mathrm{ha}^{-1} / \mathrm{h}^{-1} / \mathrm{y}^{-1}\right) ; \mathrm{K}$ is the soil erodibility factor (t/ ha $/ \mathrm{h} / \mathrm{ha}^{-1} / \mathrm{MJ}^{-1} \mathrm{~mm}^{-1}$ ); LS is the slope lengthsteepness factor (dimensionless); $C$ is the cover management factor (dimensionless); and $\mathrm{P}$ is the conservation practices factor (dimensionless).

Rainfall Erosivity (R): The $\mathrm{R}$ factor represents the erosivity of the climate at a particular location. Areas with a low slope degree have low erosivity $R$ values; whereas large numbers of $\mathrm{R}$ factor indicate more erosive weather conditions. For computing the average $R$, the recommended time duration which has to be taken is 20-25 years (Wischmeier and Smithl 1978). An alternative formula developed by Wischmeier and Smith (1978) and modified by Arnoldus (1980) involves only annual and monthly precipitation to determine the $\mathrm{R}$ factor in equation (2):

$$
R=\sum_{i=1}^{12} 1.73590\left(1.05 \log _{10}\left(\frac{P_{i}^{2}}{P}\right)-0.08188\right)
$$

Where $R$ = rainfall erosivity factor $\left(\mathrm{MJ} \mathrm{mm} / \mathrm{ha}^{-1} / \mathrm{h}^{-1} / \mathrm{y}^{-1}\right)$

$\mathrm{Pi}=$ monthly rainfall $(\mathrm{mm}), \mathrm{P}=$ annual rainfall $(\mathrm{mm})$

$K$ Factor (Soil Erodibility): Soil erodibility is predicted as a function of soil and soil profile properties like percentage of silt, very fine sand, clay, organic matter $(O M)$ and structure code (s). The regression equation for estimating erodibility factor values from the nomograph, suggested by (Wischmerier 1974) following equation (3):

$$
K=\frac{\left[2.1 \times 10^{-4}(12-O M) M^{1.14}+3.25(s-2)+2.5(p-3)\right]}{759.4}
$$

where, $\mathrm{K}=$ Soil erodibility (ton/yr/MJ/mm), $\mathrm{OM}=$ percentage of Organic Matter, ' $s$ ' = soil structural code, ' $p$ ' is permeability code and ' $\mathrm{M}$ ' is a function of soil primary particle size fractions (Appendices, eq 11). Based on the parameters' characteristics given in the above equation the K factor (soil erodibility) map can be prepared.

LS factor: Slope Length $(L)$ and Steepness $(S)$ accounts for the effects of topography on soil erosion. $(L)$ is determined using the following equation (4 and Appendix: eq14):

$$
L=\left(\frac{\lambda}{22.13}\right)^{m}
$$

Where, $22.13=$ the RUSLE unit plot length (in meters) and $\mathrm{m}=\mathrm{a}$ variable slope length exponent. Slope length is defined as the horizontal distance from the origin of overload flow to the point where either (1) the slope gradient decreases enough where deposition begins or (2) runoff becomes concentrated in a defined channel.

The slope steepness factor (S) is estimated using the relationships given by McCool et al., $(1987,1993)$. The equations (5\& 6) are as follows,

$$
\begin{gathered}
S=10.8 \sin \theta+0.03 S<9 \%(\text { i.e. } \tan \theta<0.09) \\
S=[\sin \theta / \sin 5.143]^{0.6} S<9 \%(\text { i.e. } \tan \theta<0.09)
\end{gathered}
$$

All trigonometric operations like angles have been converted into radians in ArCGIS and detailed equation expressions are given in appendix 1 (eq.12 to 17). By multiplying the $L$ factor and $S$ factor, the LS factor map can be generated in the raster format.

Cover Management Factor (C): The Cover Management factor is used to determine the relative effectiveness of soil and crop management systems in terms of preventing or reducing soil loss. Normalized Difference Vegetation Index (NDVI)- based assessment of $C$ factor is carried out by equation 7. It is used effectively to compute the spatial distribution of the $C$ factor (Kouli et al. 2009; Prasannakumar et al. 2012).

$$
C=\exp \left[-\alpha \frac{N D V I}{(\beta-N D V I)}\right]
$$

Where $\alpha$ and $\beta$ are units less parameters that determine the shape of the curve relating to NDVI and the C factor (Van der Knijff et al. 2000)

Conservation Practice Factor $(P)$ : The P factor represents the ratio of soil loss with a specific support practice to the corresponding soil loss with up and downslope (Contour) tillage (Wischmeier and Smith 1978; Renard et al. 1997; Dabral et al. 2008). It reflects the effects of practices that reduce the quantity and rate of water runoff, consequently reducing erosion levels. Using landuse and land cover, the P factor value can be generated which is $0-1 ;$ P-value of 1 indicates that there are no conservation practices in that region.

\section{Rating the factors through AHP}

Evaluation of land degradation factors, AHP based weights and scores are assigned through the nature of influence towards degradation. Analytical Hierarchy Process (AHP) is a semi-qualitative method which involves a matrix-based pairwise comparison of the contribution of different factors for land degradation. It was developed by Saaty (1980) to get factors weightage in AHP. Two-step procedures to assign the scores and weights are calculated using the geometric mean and normalization of weights. In the first step of AHP analysis, the factors are rate based on a well-defined score from a scale of 0-9 to calculate the geometric mean (Table 2). The geometric mean is calculated by dividing the total scale of weights (total score of specific factors) by the total number of parameters given in equation (8) (after Rhoad et al. 1991):

$$
\text { Geometric mean }=\frac{\text { Total scale of weight }}{\text { Total number of parameters }}
$$


The normalized weights are an indicator of multifactor analysis for land degradation assessment. The normalized weights are calculated by dividing the assigned weights of factors subclass with the corresponding geometric mean (Table 3). The formula which is represented in eq.9 (after Yu et al. 2002):

Normalised weight $=\frac{\text { Assigned weight of parameter feature class }}{\text { Geometric mean }}$

The normalized weighted map is an indicator of land degradation vulnerability zone which is classified into five classes such as very high, high, moderate, slight and low degraded zones. The class range with the maximum weight is considered as a very high vulnerable zone and the least weighted class is a less vulnerable zone for land degradation (Table 4).

\section{Land Degradation Classification Scheme}

FAO based land evaluation methodology is a prime method for assessing land degradation in the arid and semi-arid regions (FAO 1976). The structure of the land degradation system can be broadly classified into three types of decreasing level: i.e. degradation type, degradation class (degree) and degradation unit. Four different forms of land degradation are recognised as degradation types: Soil Erosion (E), Desertification (D), Salinisation (S) and Wasteland (W). Its detailed descriptions are given in Table 1.

The classes/degrees of degradation are assessed based on the severity of degradation. The classes are numbered with increasing degrees of degradation i.e. D1, D2, E1, E2....E5. Herewith, Class 1: potential degradation, but no substantiation or enriched. Class 2: Slight degradation, - (mostly vegetation degradation, affects qualitatively so its consumption rate is reduced). Class 3: moderate degradation, which is mostly influenced by vegetation and/or soil. Class 4: severe degradation, it is strongly influenced by soil, vegetation and landforms that causes to change the existing landuse practices. Class 5: very severe degradation, where land has lost its productivity and is a challenge to reclaim. The present study accomplice above said two FAO methods (i.e., degradation type and class) for the assessment of land degradation.

Land Degradation Vulnerability Index

In order to calculate the vulnerability index, the assigned AHP based sub factors weightages are divided by factors geometric mean and its normalised cumulative values are observed. Finally, all the factors normalised values are overlaid altogether and the land degradation vulnerability index (LDVI) is determined, which is given in equation 10 :

$$
\begin{aligned}
L D V I= & (L U i / L U j)+(S L i / S L j)+(E l i / E L j)+ \\
& +(S E i / S E j)+(N V i / N V j)+(P D i / P D j)
\end{aligned}
$$

Where: Lu - Landuse; SL - Slope; EL - Elevation; SE - Soil Erosion; NV - NDVI; PD - Population Density. Representation of i - Assigned Weight (AW) to individual subfactors, j - Geometric mean $(G)$.

The graphical representation of land degradation assessment methodological workflow is given in figure 2 .

Table 1. Land Degradation forms and types

\begin{tabular}{|c|c|c|}
\hline Type & Forms of land degradation & Description \\
\hline C1 & No degradation & The area is not/ somewhat degraded \\
\hline D & Desertification & $\begin{array}{r}\text { The land has been triggered by drought, wind erosion, irregular pattern of farming, overgrazing } \\
\text { and over cutting in arid or semiarid areas. }\end{array}$ \\
\hline E & Soil Erosion & Land degradation is instigated by water and wind erosion. \\
\hline S & Salinization & The land has been affected by salinization, due to poor irrigation management. \\
\hline V & Vegetation Degradation & It affects the land both quantitatively and qualitatively owing by overstocking / fuel cutting. \\
\hline W & Wasteland & Unsuitable land for any activity i.e. unreclaimed mining spots and polluted areas leads to land \\
degradation.
\end{tabular}

(FAO 1976 \& Chen Guangwei)

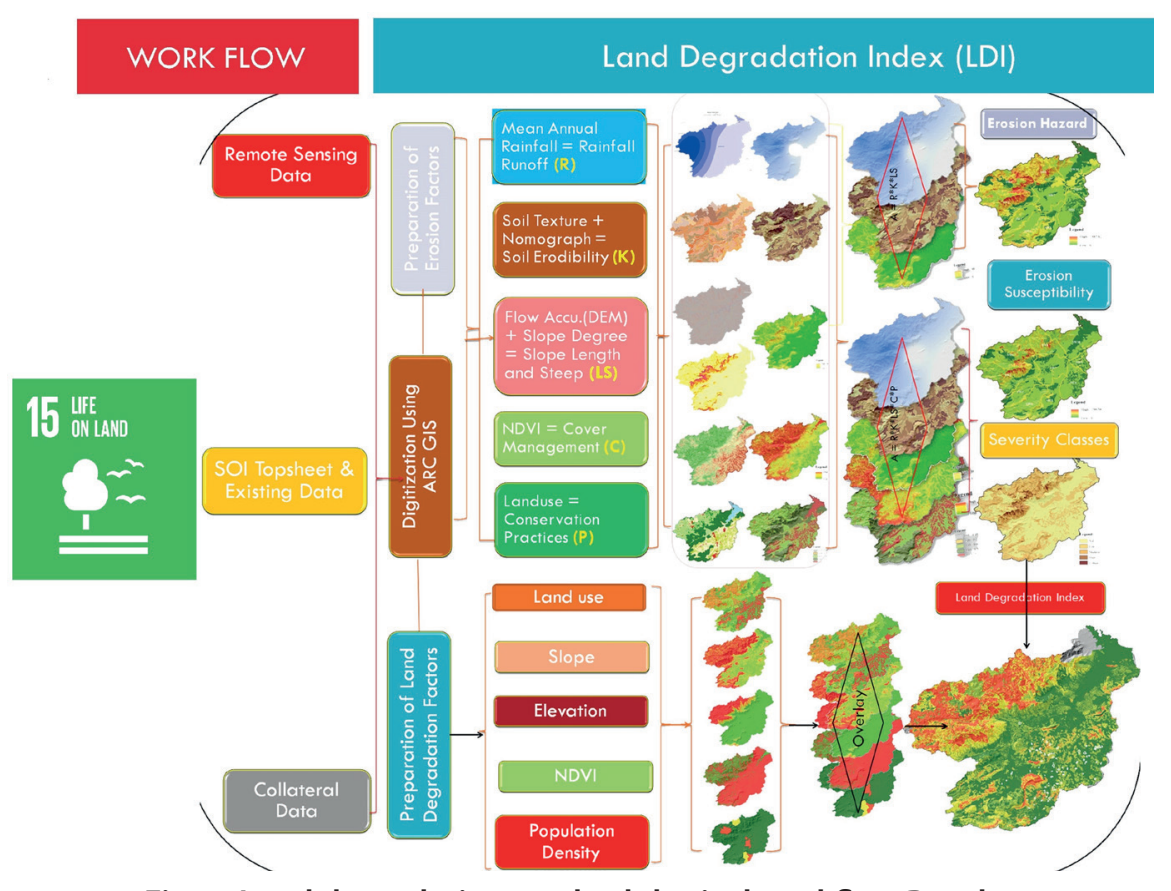

Fig. 2. Land degradation methodological workflow Results 
Results

Land degradation is a natural process or human-induced. It affects the land's ability, to function effectively within an ecosystem. It is linked to sustainability in terms of productivity. Over the years, due to population explosion, growing industrialisation, agriculture expansion and rising living standards have increased land degradation and deforestation. In this scenario the present study was conducted after conceding the above-given factors.

\section{Land Degradation Factors and Ranking}

To study land degradation in the Kallar watershed the following six thematic factors are selected: soil erosion, elevation, slope, landuse, NDVI, and population density (Figure. 4, 5, 6, \& 7). The factors and sub-factors weightages were assigned based on the impact on land degradation. Their areal extents are given in Tables (2,3 and 4). The detailed interpretation of individual factors results are given in the following sections.

Table 2. Pair-Wise Matrix for LDI Factors

\begin{tabular}{|c|c|c|c|c|c|c|}
\hline Parameters & Landuse & Slope & Elevation & NDVI & Soil Erosion & Population Density \\
\hline Landuse & $5.5 / 5.5$ & $5.5 / 5$ & $5.5 / 4$ & $5.5 / 4.5$ & $5.5 / 5$ & $5.5 / 3.5$ \\
\hline Slope & $5 / 5.5$ & $5 / 5$ & $5 / 4$ & $5 / 4.5$ & $5 / 5$ & $5 / 3.5$ \\
\hline Elevation & $4 / 5.5$ & $4 / 5$ & $4 / 4$ & $4 / 4.5$ & $4 / 5$ & $4 / 3.5$ \\
\hline NDVI & $4.5 / 5.5$ & $4.5 / 5$ & $4.5 / 4$ & $4.5 / 4.5$ & $4.5 / 5$ & $4.5 / 3.5$ \\
\hline Soil Erosion & $5 / 5.5$ & $5 / 5$ & $5 / 4$ & $5 / 4.5$ & $5 / 5$ & $5 / 3.5$ \\
\hline Population Density & $3.5 / 5.5$ & $3.5 / 5$ & $3.5 / 4$ & $3.5 / 4.5$ & $3.5 / 5$ & $3.5 / 3.5$ \\
\hline
\end{tabular}

Source: Compiled by Author

Table 3. Normalised Geometric Mean

\begin{tabular}{|c|c|c|c|c|c|c|c|}
\hline Parameters & Landuse & Slope & Elevation & NDVI & Soil Erosion & Population Density & Normalized Weight \\
\hline Landuse & 1.00 & 1.10 & 1.38 & 1.22 & 1.10 & 1.57 & 1.23 \\
\hline Slope & 0.91 & 1.00 & 1.25 & 1.11 & 1.00 & 1.43 & 1.12 \\
\hline Elevation & 0.73 & 0.80 & 1.00 & 0.89 & 0.80 & 1.14 & 0.89 \\
\hline NDVI & 0.82 & 0.90 & 1.13 & 1.00 & 0.90 & 1.29 & 1.00 \\
\hline Soil Erosion & 0.91 & 1.00 & 1.25 & 1.11 & 1.00 & 1.43 & 1.12 \\
\hline Population Density & 0.64 & 0.70 & 0.88 & 0.78 & 0.70 & 1.00 & 0.78 \\
\hline
\end{tabular}

Source: Compiled by Author

Table 4. LDI Sub-Factors Weight and Normalised Weights

\begin{tabular}{|c|c|c|c|c|}
\hline Factors & Sub Factors & Assigned weight (AW) & Geometric mean $(\mathrm{G})$ & Normalized weight ( $\mathrm{N}=\mathrm{AW} / \mathrm{G})$ \\
\hline \multirow{17}{*}{ Landuse } & Barren Rock & 0 & \multirow{17}{*}{1.23} & 0.0 \\
\hline & Built-Up Rural & 1 & & 0.8 \\
\hline & Built-Up Urban & 0 & & 0.0 \\
\hline & Crop Land & 1.5 & & 1.2 \\
\hline & Current Fallow & 8.5 & & 6.9 \\
\hline & Deciduous Forest & 7.5 & & 6.1 \\
\hline & Dense Scrub & 6 & & 4.8 \\
\hline & Evergreen Dense & 1 & & 0.8 \\
\hline & Evergreen Open & 3.5 & & 2.8 \\
\hline & Forest Plantation & 4.5 & & 3.6 \\
\hline & Industry & 1.5 & & 1.2 \\
\hline & Mine & 7.5 & & 6.1 \\
\hline & Open Scrub & 9.5 & & 7.7 \\
\hline & Plantation & 6.5 & & 5.2 \\
\hline & Reservoirs/Tank & 1 & & 0.8 \\
\hline & River & 1 & & 0.8 \\
\hline & Scrub Forest & 2.5 & & 2.0 \\
\hline
\end{tabular}




\begin{tabular}{|c|c|c|c|c|}
\hline \multirow{8}{*}{ Slope (in\%) } & Nearly Level & 1 & \multirow{8}{*}{1.12} & 0.8 \\
\hline & Very Gently Slope & 1.5 & & 1.3 \\
\hline & Gently Slope & 2.5 & & 2.2 \\
\hline & Moderately Slope & 4.5 & & 4.0 \\
\hline & Strongly Slope & 5 & & 4.4 \\
\hline & Moderately Steep to Steep & 6.5 & & 5.8 \\
\hline & Steep Slope & 7.5 & & 6.7 \\
\hline & Very Steep & 8.5 & & 7.5 \\
\hline \multirow{6}{*}{$\begin{array}{c}\text { Elevation } \\
\text { (Metre) }\end{array}$} & $<500$ & 3.5 & \multirow{6}{*}{0.89} & 3.9 \\
\hline & $500-800$ & 4.5 & & 5.0 \\
\hline & $800-1100$ & 5.5 & & 6.1 \\
\hline & $1100-1500$ & 6.5 & & 7.3 \\
\hline & $1500-1800$ & 7.5 & & 8.4 \\
\hline & $>1800$ & 8.5 & & 9.5 \\
\hline \multirow{5}{*}{$\begin{array}{c}\text { Soil } \\
\text { Erosion } \\
(\text { Ton/Ha/Y) }\end{array}$} & $<25$ & 2.5 & \multirow{5}{*}{1.12} & 2.2 \\
\hline & $25-50$ & 4 & & 3.5 \\
\hline & $50-75$ & 5.5 & & 4.9 \\
\hline & $75-100$ & 7 & & 6.2 \\
\hline & $>100$ & 8.5 & & 7.5 \\
\hline \multirow{4}{*}{ NDVI } & $<0.06$ & 0 & \multirow{4}{*}{1} & 0 \\
\hline & $0.06-0.2$ & 7.5 & & 7.5 \\
\hline & $0.2-0.4$ & 6.5 & & 6.5 \\
\hline & $0.4-0.6$ & 4.5 & & 4.5 \\
\hline \multirow{5}{*}{$\begin{array}{c}\text { Population } \\
\text { Density }\end{array}$} & $<500$ & 3.5 & \multirow{5}{*}{0.78} & 4.4 \\
\hline & $500-1000$ & 4.5 & & 5.7 \\
\hline & 1000-1500 & 5.5 & & 7.0 \\
\hline & $1500-2000$ & 6.5 & & 8.3 \\
\hline & $>2000$ & 7.5 & & 9.6 \\
\hline
\end{tabular}

\section{Soil Erosion Aspect}

Estimation of soil erosion is calculated by using RUSLE based empirical model with multi factors such as rainfall erosivity, soil erodibility, slope length and steepness, cover management, and conservation practices. The following section describes the influences and their relationship between other factors in detail.

Rainfall Erosivity (R): The annual and monthly precipitation data of twelve weather stations for a time duration of 30 years (1980-2012) were collected and the average annual rainfall was calculated. Further, it is interpolated using the geostatistical model (spline) over the whole watershed. The average annual $\mathrm{R}$ factor values ranges from 251.5 to $798.5 \mathrm{MJ} \mathrm{mm} / \mathrm{ha}^{-1} / \mathrm{h}^{-1} / \mathrm{y}^{-1}$ (Figure.3a). The high-altitude regions such as Coonoor and Gurrency have the highest range of rainfall erosivity and a decreasing trend towards northwest to southeast direction. Soil Erodibility (K): depends on soil or geological characteristics, such as parent material, texture, structure, organic matter content, porosity, catena and many more. This factor is influenced by the soil composition and soil texture. The major soil textural classes found in these areas are clay loam, clayey, loamy sand, loamy, sandy clay, sandy clay loam, and sandy loam (Figure.3b). By applying the above-said equation (3) the $\mathrm{K}$ factor values were generated and mapped. The results helped to quantitative estimation of soil erosion and express the capability or vulnerability to erode.

Slope length and Steepness (LS): This factor expresses the effect of local topography on soil erosion rate by combining the effects of slope length $(\mathrm{L})$ and slope steepness $(\mathrm{S})$ which is calculated using the equation (4-6). The longer the slope length, the greater the amount of cumulative runoff. Steeper the slope of land, higher the velocities of the runoff which contributes to erosion. By multiplying $L$ and $S$ factors, the LS factor map was generated in raster form, which ranges from 0 to 9.06 (Figure.3c). The range was higher in hilly regions with steeper slopes and lower in the plain surface.

Cover Management (C): It determines the relative effectiveness of soil and crop management systems and sinking soil loss. Normalized Difference Vegetation Index (NDVI) is used to calculate the $C$ factor (equation 7). The highest $C$ factor values indicate a high vulnerability to soil erosion, as they are considered to be unprotected barren land. The C factor ranges from $0.076-1$ 
(Figure.3d). Higher values appear in the lower regions of the study area whereas the least values are noticed in hilly areas, which is occupied by forest cover. Conservation Practice (P): It is the ratio of soil loss in normal conditions to the soil loss due to plowing. The P factor map was derived from the landuse / land cover and support factors. The values of $P$ factor ranges from 0 to 1 (Fig. 3e). Open areas and grasslands are more prone to soil erosion since they have the highest values with no conservation practices. Minimum values were recorded in built-up land and plantation areas with contour cropping practices that are less prone to erosion. Common support practices such as cross slope cultivation, contour farming, strip cropping, terracing, and grassed waterways are adopted in these regions.

Soil erosion: By integrating all the five thematic layers, the severity of soil erosion and loss is calculated through equation (1). Due to the erosion of more fertile soil, the land quality and its nutrients will be lost. These lands become useless and are instantly converted to cultural wastelands. Finally, it leads to land degradation. By effective utilisation of the RUSLE model, soil loss due to erosion has been carefully estimated at the pixel level. The soil loss rate is classified into five erosion severity classes (Figure.4). Potential annual soil loss is carefully estimated from the desired product of contributing factors $(R, K, L S, C$, and $P$ ) in

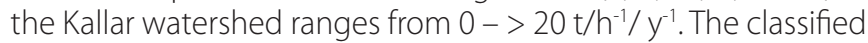
soil loss map shows that about $50.6 \%$ of the total area has very less erosion with a tolerable rate of $<2 \mathrm{t} / \mathrm{h}^{-1} / \mathrm{y}^{-1}$, followed by $7.6 \%$ have less soil loss with the rate of soil erosion $2-4 t / h^{-1} / \mathrm{y}^{-1}$. About $8.5 \%$ of the considered area is under moderate erosion with the soil loss of $4-8 \mathrm{t} / \mathrm{h}^{-1} / \mathrm{y}^{-1}$. The high rate of $8-20 \mathrm{t} / \mathrm{h}^{-1} / \mathrm{y}^{-1}$ typically covers a sensitive area of $20.3 \%$ and $13 \%$ is prone to very high erosion with the soil loss of $>20 \mathrm{t}^{\mathrm{h}} \mathrm{h}^{-1} / \mathrm{y}^{-1}$ on very steep slopes which is covered with deciduous forest. Estimated soil erosion severity classes were compared with other alternative factors related to the possible vulnerability of land degradation; which incurred the second-highest geometric mean of 1.12. The soil erosion sub-factors were further assigned weights individually that are shown in table (4). By multiplying both erosions factor geometric means with its sub-factors individual weights, the normalised weightage was computed.

After estimating the soil erosion severity classes, the computed values of $R, K, L S, C$ and $P$ were further classified into two categories: (1) Soil erosion susceptibility A=RKLS (2) Soil erosion hazard $A=$ RKLSCP (Fig. 5 a \& b). These categories provide insights into real variations of these values. However, RKLS values indicate soil loss, if crop management and erosion control practices are absent. The lowest values of RKLS represent figures for plains (flat to gentle) and the highest for those of hills. On the other hand, RKLSCP values indicate soil loss in the plains (lowest values) where crop management and erosion control practices are persistent. To reduce the loss of soil in the hills which has the highest values, conservation practices are implemented. When measuring the rate of soil erosion, it is found that the RKLS values are comparatively higher than RKLSCP values.

An intriguing inference has been drawn from the two values concerning the highest values (RKLS and RKLSCP). For instance, in the absence of crop management, the watershed has a soil loss of $447.3 \mathrm{t} / \mathrm{h}^{-1} / \mathrm{y}^{-1}$ but a glance at the RKLSCP value

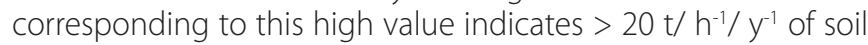
which is mainly attributable to the forest cover.

\section{Terrain Aspect}

While assessing land degradation slope and elevation (relief) factors are dominant. They were extracted from ASTER DEM. To understand the stability of the terrain, slope maps were generated and categorised into eight classes: nearly level, very gentle, gentle, moderate, strong, moderately steep, steep, and very steep (Fig. 6a, b). Of which $44.5 \%$ of the geographic area is covered by moderately steep to very steep, $26.2 \%$ of the area is occupied by very steep slope. An overall weightage of 1.12 is allotted to the slope factor. Among the slope class, the steep to very steep slope class is more prone to land degradation due to irregular cropping patterns. This class has been assigned the highest rank of 8.5 and 7.5 , respectively. The least rank (1)
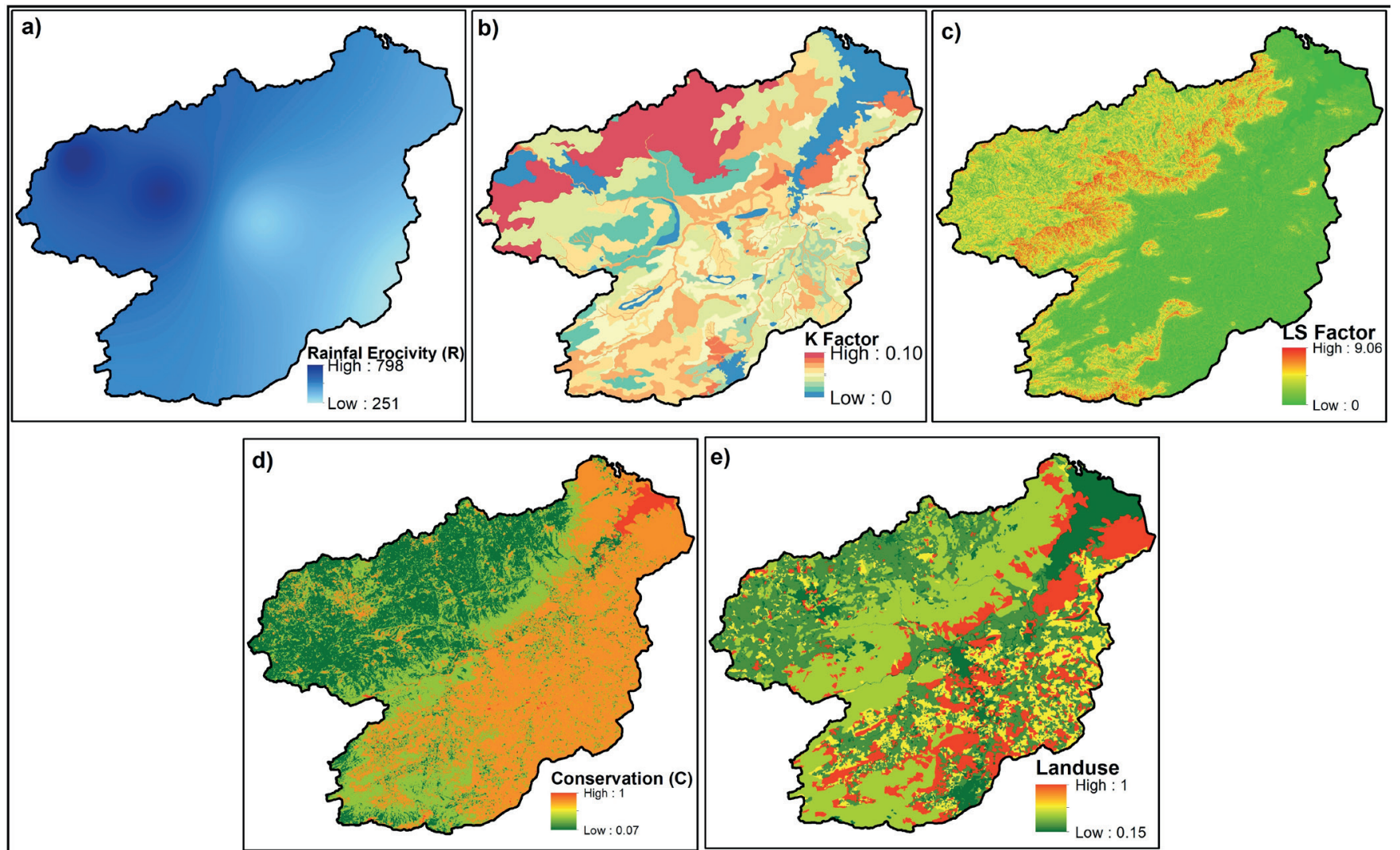

Fig. 3. a) Rainfall Erosivity, b) Soil Erodibility c) Slope length and steepness d) Conservation Practices e) Cover Management 


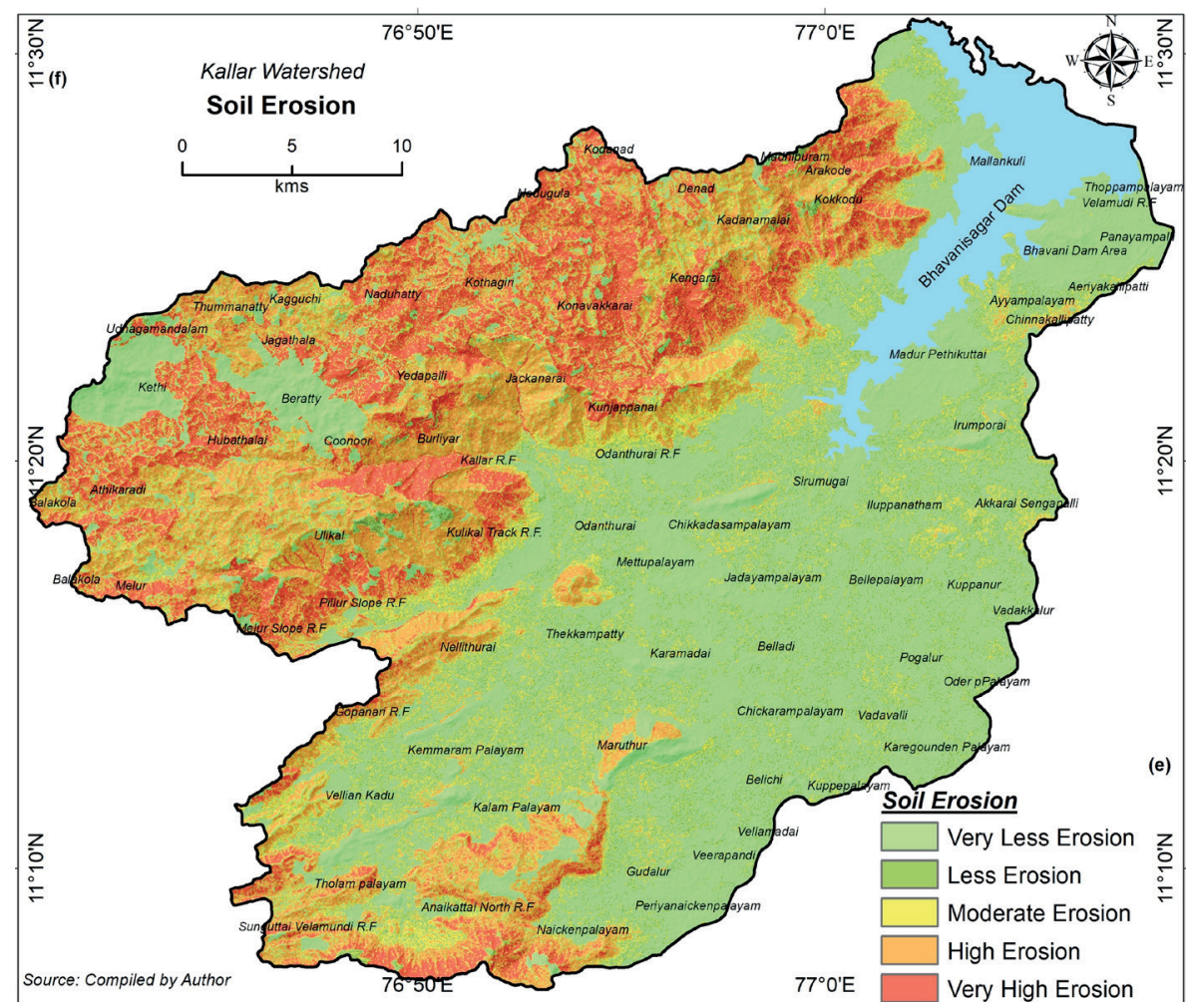

Fig. 4. Soil Erosion Loss

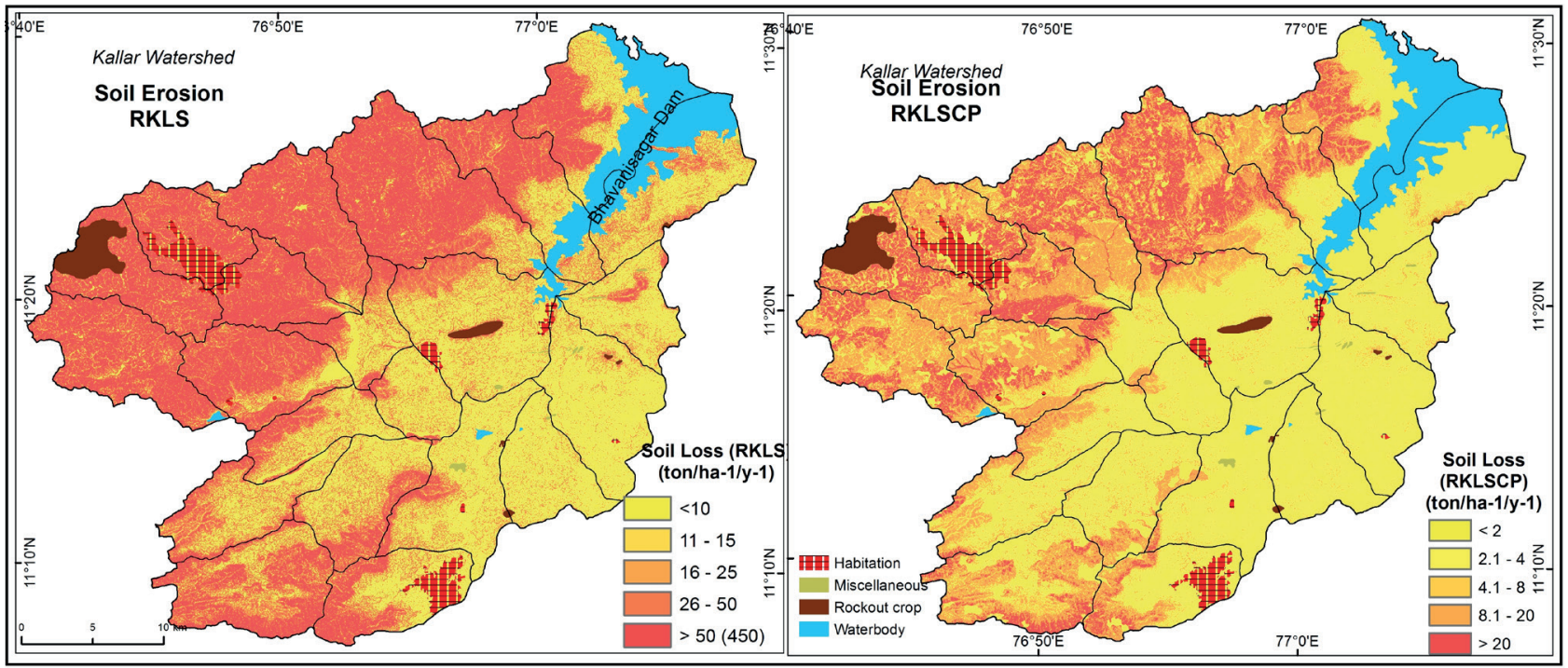

Fig. 5. a) Soil erosion susceptibility (RKLS) b) Soil erosion hazard (RKLSCP)

was assigned to the nearly level slope which represents less possibilities of degradation. Relatively, the role of elevation in the land degradation process is similar to the slope of the land. Higher the altitude, greater the degradation. These land areas have less slope stability and high erosion. Further these elevations are classified into $>1800 \mathrm{~m}, 1500-1800,1100-1500$, 800-1100, 500- 800 and < 500 m (Fig. 6c \& d). The present study area shares two various topographies such as mountains with upland plateaus and plains. A weightage of 0.89 was allotted to terrain factor and its sub-classes were assigned weights which is given in (Table 4).

\section{Environmental Aspect}

Among all the selected land degradation vulnerability factors, landuse secured the highest score of 1.28 from both aspects naturally induced process and human activities. In the present study area, landuse classes are broadly categorised into five classes i.e., 1) Built-up (urban and rural); 2) Agricultural (cropland, plantation and current fallow land) and 3) Forest (evergreen dense, evergreen open, deciduous and forest plantation). 4) Wasteland (barren rock, dense scrub, open scrub, scrub forest, mining) and 5) Waterbody (reservoirs/tank and river) (Fig. 7a). Stretching from north-west to east, the Nilgiri reserve forest dominates the forest cover in this region. Outer sloping and foothill areas comprised of deciduous forests, dense and open scrub forests, which are vulnerable to land and forest degradation. Within this landuse class, open scrub, current fallow, mining and the deciduous forest have been given the highest ranking of $9.5,8.5 \& 7.5$ respectively (Fig. $7 \mathrm{~b}$ ). Due to this, these classes are more prone to land degradation when compared with other landuse classes and the least rank is given to built-up areas. NDVI represents vegetation and non-vegetation areas (Fig. 8a). They have been assigned an intermediate weight of 1 and the subclass of NDVI range $<0.4$ has been given the highest rank of 7.5. The least rank of 4.5 has been allotted to a range of $>0.4$ (Fig. 8b). The range less than 0.4 signifies non-vegetative areas which are mostly covered by barren land and scrubland. 


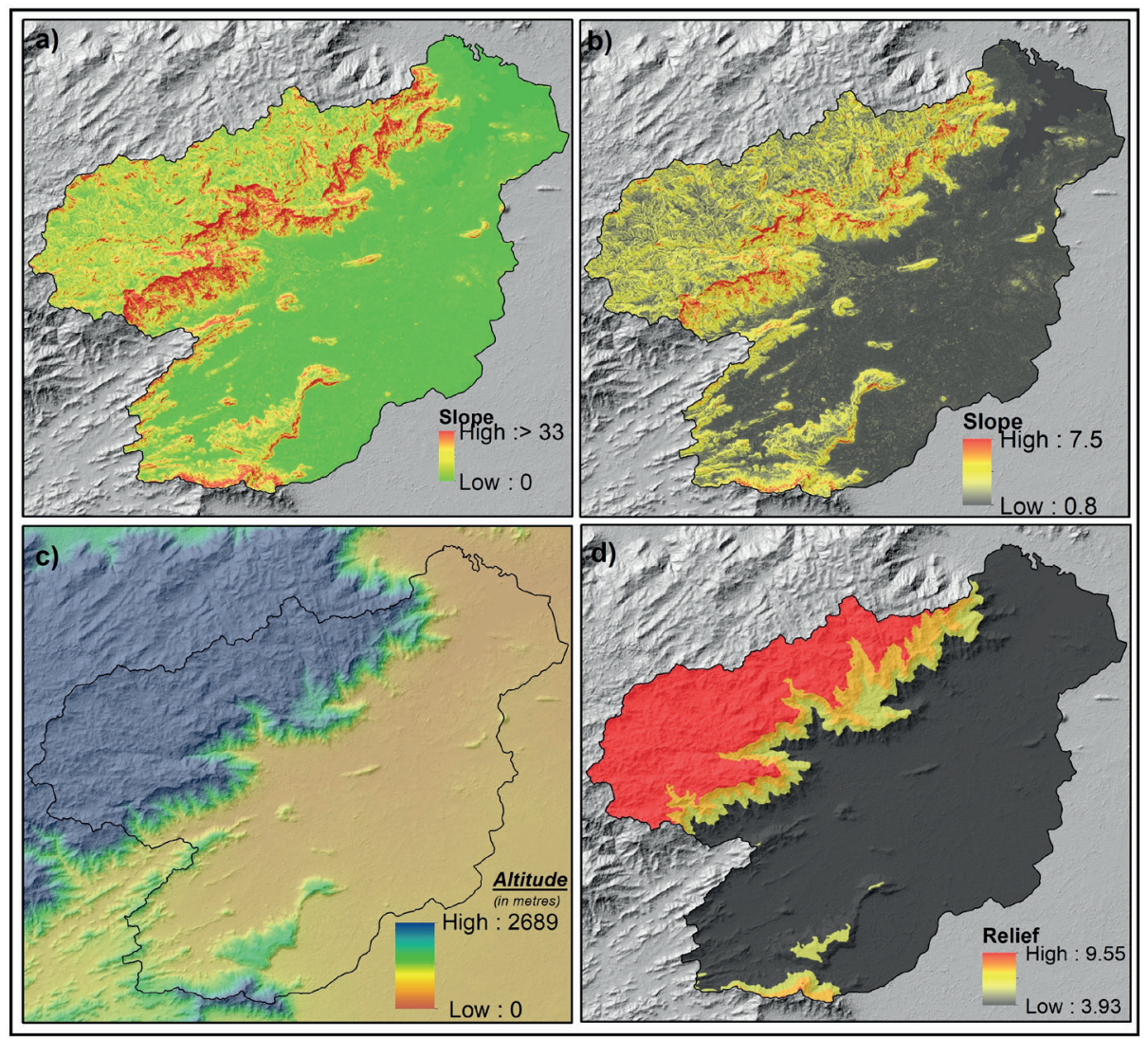

Fig. 6. a) Slope b) Weighted Slope c) Relief d) Weighted Relief

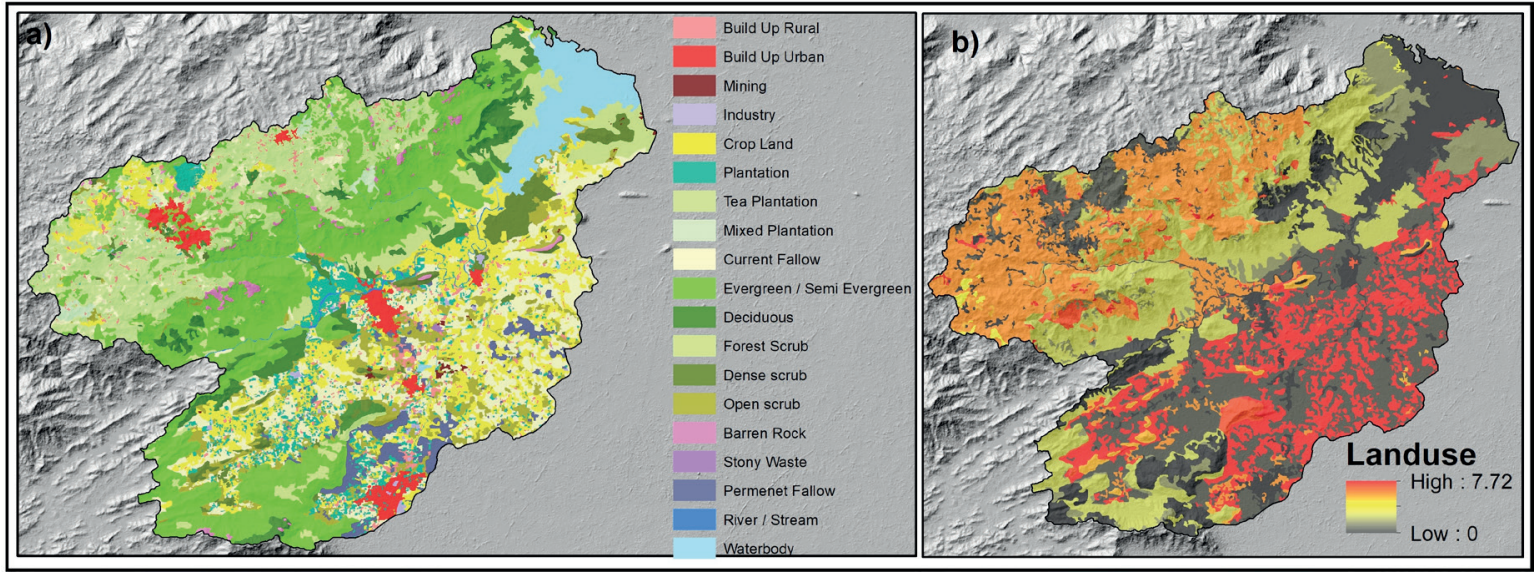

Fig. 7. a) Landuse b) Weighted Landuse

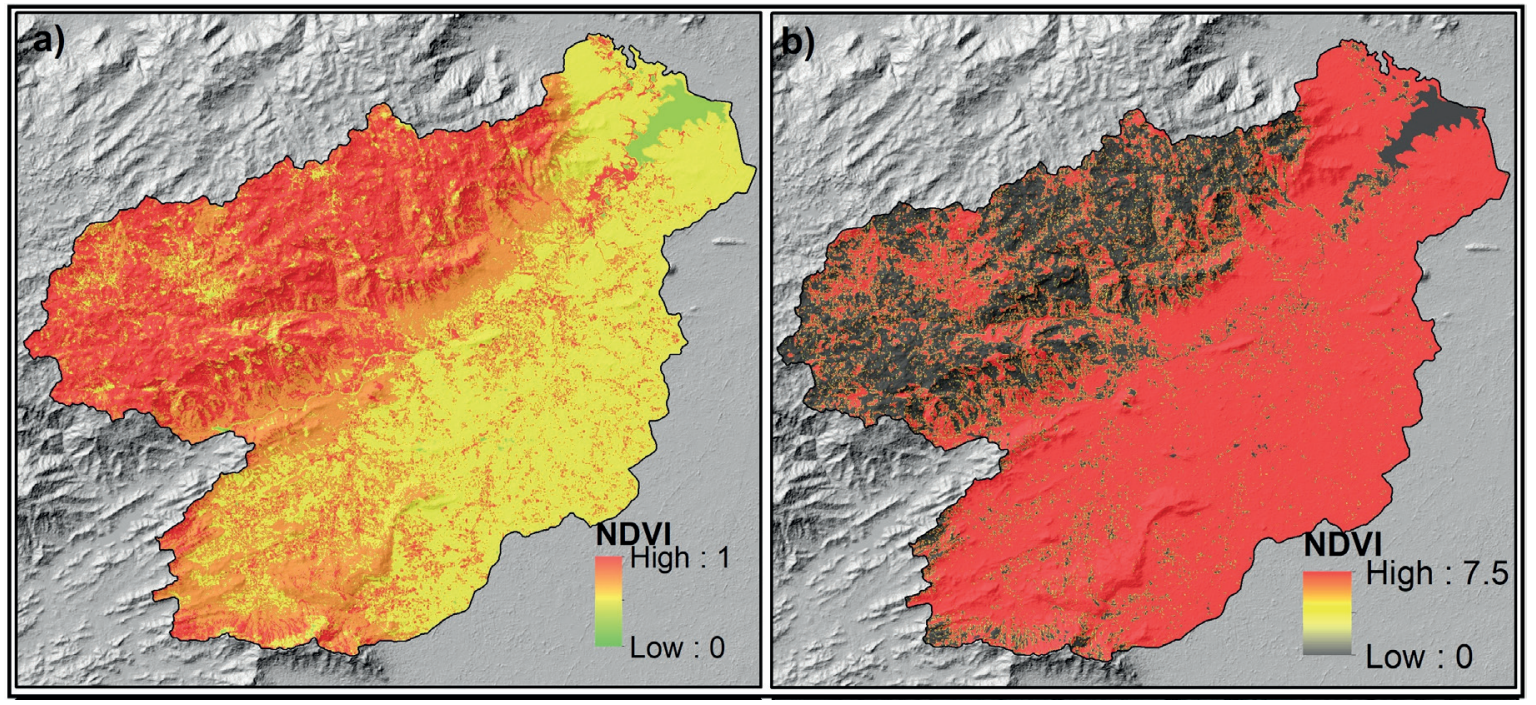

Fig. 8. a) NDVI b) Weighted NDVI 
From a human perspective of land degradation, various demographic factors are influenced directly and indirectly i.e., population growth, density, households, literacy and sex ratio. Population density has been chosen as the common demographic factor. Population density has been given the least weight (0.78), even though it is an important hidden factor for land degradation. A high population density pressurises to more land degradation in various aspects, i.e., solid waste disposal, improper wastewater management, rapid urbanization and the need for more food production. The population density sub classes $>2000$ persons/sq.km are noticed in Coonoor, Mettupalayam and Periyanayakanpalayam, which has been allotted the highest rank of 7.5. Followed by intermediate ranks (6.5, 5.5, and 4.5) assigned to 1500-2000, 1000-1500, 500-1000 persons/sq.km respectively. < 500 persons/ sq. km has been assigned to the least rank of 3.5. Spatial distribution and weighted map of population density are shown in Figures 9a \&b.

\section{Land Degradation Vulnerability Index}

The six thematic layers (landuse, slope, elevation, soil erosion, NDVI, and population density) were used for the assessment of land degradation. The final cumulative land degradation vulnerability index map was generated by using equation (10). Further, it was classified into five classes such as Severely Degraded, Highly Degraded, Marginally Degraded, Moderately Degraded, and Less Degraded. The spatial distribution and their areal extent are given in Figure. 10 and Table 5.

Low Degraded (D1): This class includes agricultural lands consisting of moderate -to- gentle slopes, very slight erosion and intact topsoil layer. Low degraded class is mostly found in the lower region of the Kallar watershed and occupies an area of 38.3\% (49177 ha).

Moderately (D2): Moderately dense forests, grazed and disturbed grasslands and agriculture in moderate to steep slopes with rills and small gullies, and signs of root exposure fall under this class. These classes are mostly seen in the foothill areas and are adjacent to high-degraded areas. This region occupies an area of 39\% (50059.7 ha), which require moderate conservation practices to control land degradation.

Marginally Degraded (D3): Sparse forests (vegetation), modified natural grasslands, tea plantation and pastures, moderate - to - steep slopes, absence of large gullies and tree uprooting fall under this category which covers 15.4\% of the area.

Severely \& Highly Degraded (D4 \& D5): These classes occupy an area of about $22.6 \%$ of the total geographic area. These areas consist of moderate-to-open forests, poor cultivation, steep to very steep slopes, severely eroded areas with or without gullies and tree cover uprooting. Mostly D5 and D4 classes are noticed in the northwest part of the Kallar watershed. These regions are dominated by tea plantations and deciduous forests, with less tree crown cover density; this leads to soil erosion. Further, in the upland plateau regions, irregular agricultural activity is practiced.

In recent years, several parcels of the fertile agricultural lands are converted into settlement plots (Fig. 10 highlighted in white color). For many years, these land areas are either laying wasted without any productivity and waiting for construction or re-sale. Hence, an appropriate landuse policy should be promulgated.

\section{DISCUSSION}

Numerous factors on environments cause direct or indirect changes in the process of the system such as LULC transformation, climate change, socio-economic factors, cultural and demographic factors (Uzun and Somuncu 2013; Temiz et al. 2017; Olena 2017; Abhijeet et al. 2020). This study utilised multifaceted factors like climatic, environmental, terrain and demographic factors to assess land degradation along with its strength and weakness of the watershed. An absence of global agreement on the definition of land degradation and a standardised methodology for its assessment at different spatial scales (Metternicht et al. 2010; Higginbottom and Symeonakis 2014) are major limitations of the study. There is not an approved or recommended methodology to evaluate the selected SDG targets and indicators with limited input parameters. Hence, this study has framed a new methodology of integrating physical and empirical model-based, physio-climatic, and socio-environmental inputs to address the issues through geospatial techniques and multicriteria decision making. This research will be an ideal solution to assess land and forest degradation. It is a combination of multi-facet parameters such as physical, environmental and socio-economic aspects. The study evaluates and helps policymakers to take decisions with appropriate conservation measures to fulfil sustainability goals at local and global levels.

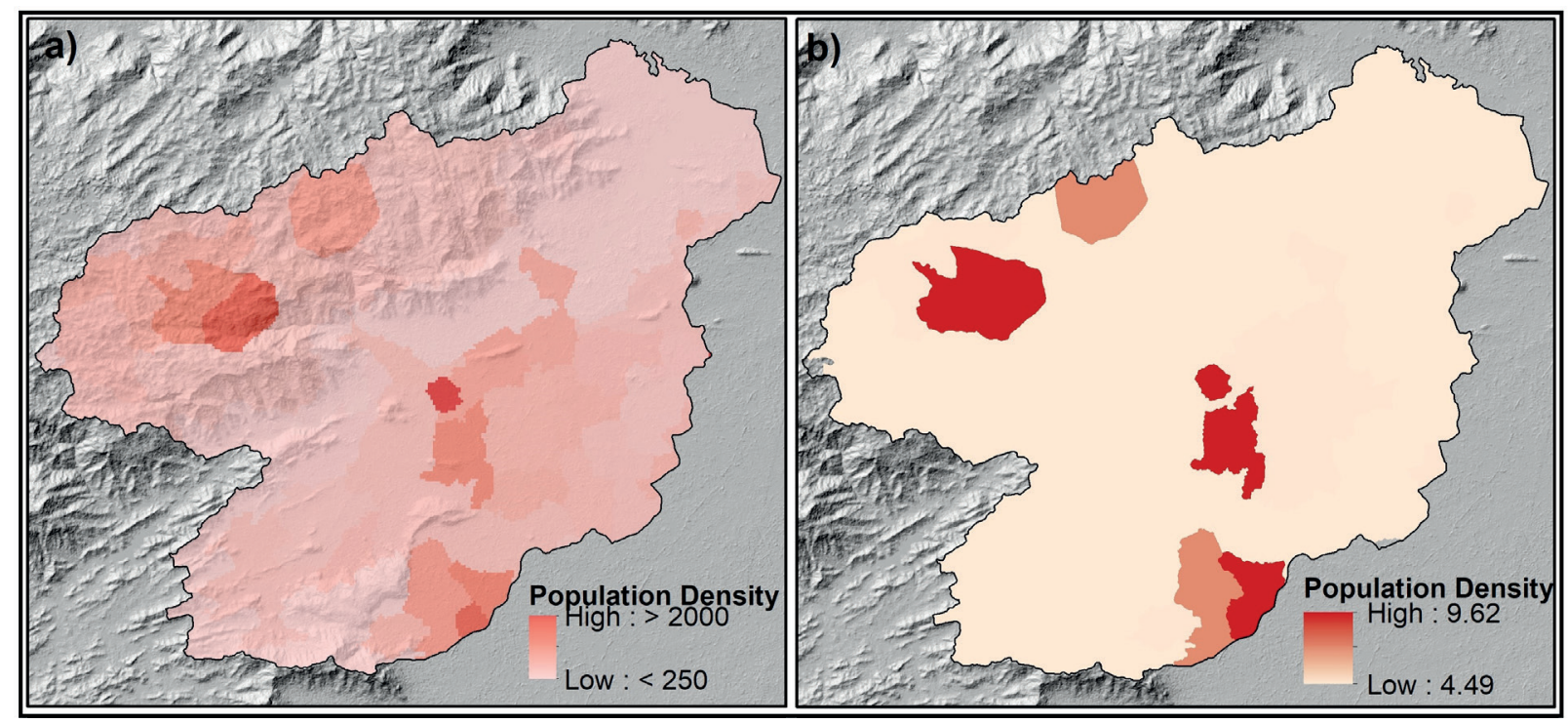

Fig. 9. a) Population Density b) Weighted Population Density 


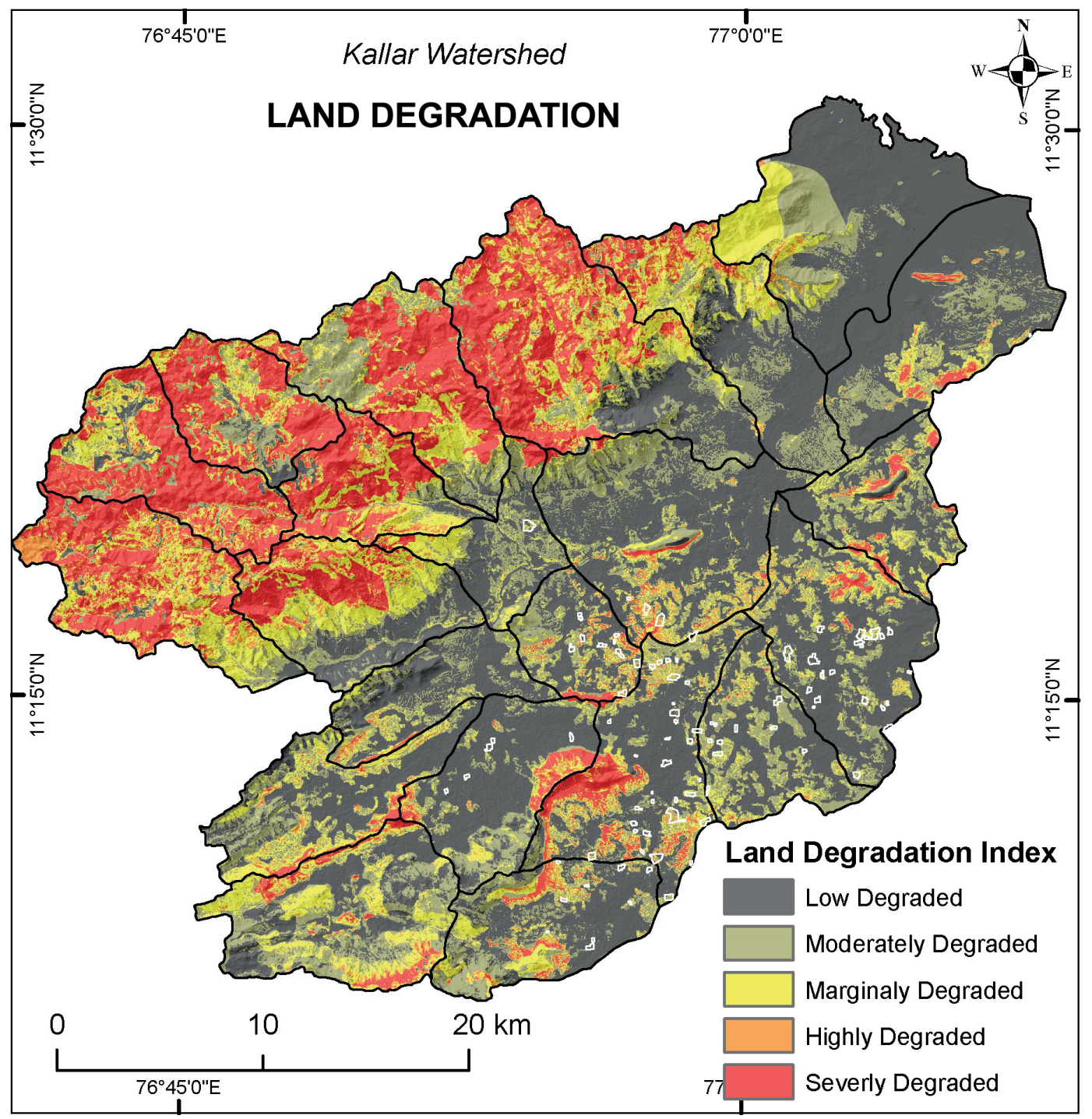

Fig. 10. Land Degradation Index

Table 5. Land degradation class and spatial extend

\begin{tabular}{|c|c|c|}
\hline Land Degradation Class & Area (in Ha) & Area (\%) \\
\hline Low Degraded & $49,177.4$ & 23.3 \\
\hline Moderately Degraded & $30,258.6$ & 15.4 \\
\hline Marginally Degraded & $19,801.0$ & 4.8 \\
\hline Highly Degraded & $6,199.5$ & 17.8 \\
\hline Severely Degraded & $22,809.1$ & 100 \\
\hline Total Area & $128,245.6$ & \\
\hline
\end{tabular}

Source: Compiled by Author

From the natural perspective of land degradation, terrain with moderate to steep slope areas are highly prone to soil degradation, which leads to soil erosion during heavy rainfall. It reduces the infiltration rate. This can be seen in the foothill regions which are covered by deciduous forests (sparse trees) and less density of tree crown cover. Due to its nature of topography which consists of hilly terrains, steep slopes and dense forests, the Kallar watershed has a higher possibility of soil erosion. About 30\% of the area is covered by various types of forest cover i.e., evergreen, deciduous, and open scrub forest, which is located in the middle of the watershed. Due to this, human and natural forces in this area result in deforestation and land degradation. During the summer monsoon, these deciduous forest areas are frequently affected by severe drought and forest fires. Human activity is higher in moderate slope regions than mountainous terrains and foothills. Human activities in this forest land includes cultivable land and other social activities. It creates forest degradation; the extension of the mentioned processes finally leads to deforestation. The previous studies of Rahaman and Venkatesh (2020), stated that deciduous forest and forest scrub areas are under the degradation stage, which causes environmental degradation in the Nilgiri Biosphere Revere of Western Ghats.

The Kallar watershed has a maximum annual soil loss of $398.5 \mathrm{t} / \mathrm{h}^{-1} / \mathrm{y}^{-1}$ and $>100 \mathrm{ton} / \mathrm{h}^{-1} / \mathrm{y}^{-1}$ is about $15 \%\left(200 \mathrm{~km}^{2}\right)$ of the geographic area (Abdul et al. 2015). Similarly, soil and 
water losses are serious issues in the western Liaoning low mountains and hills of China, which has erosion rates of up to 3000-5000 t/ $\mathrm{km}^{-1} /$ year ${ }^{-1}$ are observed (Zhao et al. 1992). Due to severe soil erosion, removal of top layer soil, and declining soil fertility, which causes decreasing land productivity. Through soil erosion susceptibility (RKLS) and soil erosion hazard (RKLSCP), it is understood that the functions of $C$ and $P$ factors can be controlled and thus can greatly reduce soil loss through proper management and conservational measures. The terrain of a region largely determines its suitability for human settlement. Flatter alluvial plains tend to have better farming soils than steeper and rocky uplands. In the present study region, half of the area is covered by forest which is reserved and open type. There are more possibilities of land degradation in the outer fringe of evergreen forests due to human activity. This leads to deforestation and loss of biodiversity richness in this region (Abdul 2016).

Due to the favourable climatic and topographic conditions found in the upper portion of the watershed, this natural land cover (forest) is converted to tea plantations and is used for grazing. The southern regions of the study area can be categorised into agricultural land, current fallow land and other wastelands. In this area, productive agricultural lands are converted into settlement plots due to water scarcity and less quantity of soil nutrients. If this situation persists, the entire area will be affected and will result in agricultural drought and severe land degradation. A detailed qualitative, quantitative analysis and a comparative study has been conducted in the Kallar watershed. The analysed resultant values are classified into five classes based on FAO land evaluation approaches such as: Severely, highly, moderately, marginally, and low degraded.

Further, the outcome of the study was compared and validated with existing results published by the SAC, ISRO; Google Earth Image and IRS LISS IV image along with field verification. 92 settlement plots were identified and mapped (Figure 8a). Under the guidance of the Indian Space Research Organisation (ISRO) and with the help of Space Application Centre (SAC), national-level Desertification and Land Degradation Atlas of India was prepared, using Indian Remote sensing Satellite (IRS), Advanced Wide Field Sensor (A WiFS) data of 2011-13 and 2003-05 (SAC, ISRO, 2016). The analysis depicts that 96.4 million hectares ( $\mathrm{mha}$ ) of land area in the country have undergone land degradation i.e., 29.3\% of the total geographic area of the country during 2011-13. According to a sensitive assessment by the Indian Council of Agricultural Research (ICAR 2010), about 120.4 mha (out of $328.7 \mathrm{mha}$ ) of land area in the country was affected by land degradation during 2009-10.

By examining the biophysical and demographic factors, they can be distinguished to provide optimal solutions for selected SDG's (15.3) and their targets (15.3.1 \& 3) like sustainable forest management and land that is degraded over the total land area. FAO serves as a contributing agency for some of the indicators including 15.3.1. It suggests the following sub-indicators: 1) Land cover and landcover change; 2) Land productivity; and 3) Carbon stocks above and below ground (UNCCD 2015 and FAO 2018) for «good practice guidence» in the measurement and evaluation of changes. SDG goals, targets, indicators, and sub-indicators have to be addressed and implemented. They require substantial strategies like defining land and forest degradation, measuring its extent, and evaluating spatial dimensions at the local, regional, and global scale. To assess degradation, appropriate indicators like land use, climate, and population have to be determined. Reducing anthropogenic influences on the degraded areas ensures rejuvenation of the natural state of the land areas. Userdriven and participatory approaches at the rural level should be encouraged to achieve sustainability.

The study reveals that the Kallar watershed is under severe threat of soil erosion and degradation of forest and land. Continuation of these practices in the current scenario will make this area to the most vulnerable hotspot for land degradation. In this situation, proper conservation management like changing agricultural practices in the plain areas; contour bunds, terrace cultivation on high-altitude regions, construction of check dams, and percolation ponds to control the water scarcity is extremely essential. Strict landuse policies have to be implemented to control and stop the conversion of fertile agricultural lands for other activities. Protection of forest areas, minimizing deforestation and practicing afforestation is highly recommended. The extension of this work should be carried forward to estimate land productivity, land cover changes and biomass at the regional and national levels. Public awareness has to be created and appropriate conservation measures to protect land sustainability have to be taken.

\section{CONCLUSION}

The study utilises various modern techniques of geospatial technology coupled with multi-criteria evaluation methods to assess the vulnerability of land degradation by natural and anthropogenic activity. Hence standardized methodology for land degradation assessment at different spatial scales is the major limitation of this study. However, soil erosion, overpopulation, reduction in forest density, overgrazing and inadequate conservation measures are the main causes of land degradation in the Kallar watershed. Both natural and human-induced multi influential factors were chosen to evaluate the degree of land degradation. Soil erosion plays a major role in the land degradation processes at the foothill areas which has the least agricultural activity. Further, the resultant classes were cross-validated with the field and Google earth images. In many places, cultivable land areas are converted to construction plots or permanent fallow lands (wasteland). By replacing land exploitation with land conservation practices, cautious utilization of the land resource can be adopted. Based on the analysis, it is observed that the Kallar watershed is prone to very high to high degradation stage. The land area has to be controlled and monitored regularly with the aid of advanced technologies.

A strategic measure to prevent loss of soil and water and minimize ecological disturbances, the development of forestry can be accelerated. Practicing afforestation in degraded forest areas to enrich soil nutrition, increases the availability of water. To reduce soil erosion, implementing various engineering and biological conservation measures such as conversion of land on slopes to fallow and gully engineering techniques can be adopted. Modern agricultural practices that includes farming between ridges across the slope and inter-cropping along the contour belt should be encouraged. Planting fruit trees and growing herbals can be enriching the ecosystem. This is an important strategic measure for developing the economy which helps in ecological conditions in mountain areas and maintaining ecological balance. Further, the implementation of efficient land system management and landuse policies to protect the natural environment through sustainable approaches in the Kallar watershed is crucial for future generations. The imminent scope of the present study pursued through advanced machine learning algorithms is used to monitor the environment, assess biomass estimation, and evaluate ecological assessment for a sustainable environment. 


\section{REFERENCES}

Abdul Rahaman S., Aruchamy S. and Jegankumar R. (2014). Geospatial approach on landslide hazard zonation mapping using multicriteria decision analysis: a study on Coonoor and Ooty, part of Kallar watershed, The Nilgiris, Tamil Nadu, Int. Arch. Photo. Remot Sens. Spatial Inf. Sci., XL-8, 1417-1422, DOI: 10.5194/isprsarchives-XL-8-1417-2014.

Abdul Rahaman S., Aruchamy S., Jegankumar R. and Abdul Ajeez S. (2015). Estimation of annual average soil loss, based on rusle model in Kallar watershed, Bhavani basin, Tamil Nadu, India, ISPRS Ann. Photogramm. Remote Sens. Spatial Inf. Sci., II-2/W2, 207-214, DOI: 10.5194/ isprsannals-II-2-W2-207-2015.

Abhijeet Ghadge, Sjoerd van der Werf, Merve Er Kara, Mohit Goswami, Pankaj Kumar, Michael Bourlakis (2020). Modelling the impact of climate change risk on bioethanol supply chains, Technological Forecasting \& Social Change 160, DOI: 10.1016/j.techfore.2020.120227.

Arnoldus H.M.J. (1980). An approximation of the rainfall factor in the Universal Soil Loss Equation.

Angima S.D., Stott D.E., O'Neill M.K., Ong C.K. and Weesies G.A. (2003). Soil erosion prediction using RUSLE for central Kenyan highland conditions agriculture. Ecosystems and Environment, 97(1-3), 295-308.

Barzani and Khairulmaini (2013). Desertification risk mapping of the Zayandeh Rood Basin in Iran. Journal of Earth System Science 122(5), 1269-1282, DOI: 10.1007/s12040-013-0348-1.

Bhattacharyya R., Ghosh B.N., Mishra P.K., Mandal B., Rao C.S. and Sarkar D. (2015). Soil degradation in India: challenges and potential solutions. Sustainability 7, 3528-3570.

Barrow C. (1994). Land degradation development and breakdown of terrestrial environments. Cambridge University Press, New York. Brevik E.C., Cerda A., Mataix-Solera J., Pereg L., Quinton J.N. Six, J. and Van Oost K. (2015). The interdisciplinary nature of soil, Soil, 1, 117129, DOl: 10.5194/soil-1-117-2015.

Camprubi A., Zarate I.A., Adholeya A., Lovato P.E. and Calvet C. (2015). Field performance and essential oil production of mycorrhizal rosemary in restoration low-nutrient soils, Land Degrad. Dev., 26, 793-799, DOI: 10.1002/ldr.2229.

Cerda A., Gonzalez-Pelayo O., Gimenez-Morera A., Jordan A., Pereira P., Novara A., Brevik E.C., Prosdocimi M., Mahmoodabadi M., Keesstra S., Garcia Orenes F. and Ritsema C. (2016). The use of barley straw residues to avoid high erosion and runoff rates on persimmon plantations in Eastern Spain under low frequency - high magnitude simulated rainfall events, Soil Res., 54, 154-165, DOI: 10.1071/SR15092.

Christopher Morgan (1983). The non-independence of rainfall erosivity and soil erodibility, Earth Surface Processes and Landforms, 8 , 323-338.

Chen Guangwei (1994). Land Degradation Approach - Methodology and Practice, CISNAR, China.

Dabral P.P., Baithuri N. and Pandey A. (2008). Soil erosion assessment in a hilly catchment of North Eastern India using USLE, GIS and remote sensing. Water Resources Management, 22, 1783-1798.

De Boodt M. and Gabriels D. (Eds.) (1980). Assessment of Erosion, Wiley, Chichester, UK, 127-132.

Desertification and Land Degradation Atlas of India (2016). (Based on IRS AWiFS data of 2011-13 and 2003-05), Space Applications Centre, ISRO, Ahmedabad, India.

D'Odorico P.; Bhattachan A., Davis K.F., Ravi S. and Runyan C.W. (2013). Global desertification: Drivers and feedbacks. Adv. Water Resour., 51, 326-344.

Eisfelder C., Kuenzer C. and Dech S. (2012). Derivation of biomass information for semi-arid areas using remote-sensing data. Int. J. Remote Sens., 33, 2937-2984.

Eliasson K., Lindgren U. and Westerlund O. (2003). Geographical labour mobility: Migration or commuting. Regional Studies 37, $827-37$. El-Swaify S.A. (1997). Factors affecting soil erosion hazards and conservation needs for tropical steeplands. Soil Technology 11, 3-6.

FAO (1976). A Framework for Land Evaluation. FAO Soil Bulletin No. 32. ILRI Publication No. 22. Rome, Italy.

FAO (1980). Natural resources and the human environment for food and agriculture. Environment Paper No 1. Rome. Rome.

FAO (1990). Rural area development planning; A review and synthesis of approaches. FAO training materials for agricultural planning.

FAO (2018). LDN - Restoring degraded lands. http://www.fao.org/land-water/land/ldn/en/

Feizizadeh B. and Blaschke T. (2014). An uncertainty and sensitivity analysis approach for GIS-based multicriteria landslide susceptibility mapping, International Journal of Geographical Information Science, 28:3, 610-638, DOI: 10.1080/13658816.2013.869821.

Gessesse B., Bewket W. and Brauning A. (2015). Model-based characterization and monitoring of runoff and soil erosion in response to landuse/land cover changes in the Modjo Watershed, Ethiopia, Land Degrad. Dev., 26, 711-724, DOI: 10.1002/ldr.2276.

Higginbottom T.P. and Symeonakis E. (2014). Assessing land degradation and desertification using vegetation index data: Current frameworks and future directions. Remote Sensing, 6(10), 9552-9575, DOI: 10.3390/rs6109552

Helldén U. (2008). Tottrup C. Regional desertification: A global synthesis. Glob. Planet. Chang. 64, 169-176.

Haboudane D., Bonn F., Royer A., Sommer S. and MehI W. (2002). Land degradation and erosion risk mapping by fusion of spectrallybased information and digital geomorphometric attributes. Int. J. Remote Sens., 23, 3795-3820.

ICAR (Indian Council of Agricultural Research) (2010). State of Indian Agriculture, 2012-2013, A report of Department of Agriculture and Cooperation, New Delhi, 9.

IPCC (2001). Intergovernmental Panel on Climatic Change, «lmpacts, Adaptation and Vulnerability».

Jong R.D., Bruin S.D. and Dent M.S.D. (2011). Quantitative mapping of global land degradation using earth observations. Int. J. Remote Sens., 32, 6823-6853.

Jasrotia A.S. and Singh R. (2006). Modeling runoff and soil erosion in a catchment area, using the GIS, in the Himalayan region, India. Environ Geol 51, 29-37, DOI: 10.1007/s00254-006-0301-6.

Khaledian Y., Kiani F., Ebrahimi S., Brevik E.C. and Aitkenhead-Peterson J. (2017). Assessment and monitoring of soil degradation during landuse change using multivariate analysis, Land Degrad. Dev., 28, 128-141, DOl: 10.1002/ldr.2541.

Kouli M., Soupios P. and Vallianatos F. (2009). Soil erosion prediction using the Revised Universal Soil Loss Equation (RUSLE) in a GIS framework, Chania, Northwestern Crete, Greece Environmental Geology, 57, 483-497.

Leh M., Bajwa S. and Chaubey I. (2013). Impact of landuse change on erosion risk: an integrated remote sensing, geographic information system and modelling methodology, Land Degrad. Dev., 24, 409-421, DOI: 10.1002/ldr.1137.

Lin D.G., Yu H., Lian F., Wang J.A., Zhu A.X. and Yue Y.J. (2016). Quantifying the hazardous impacts of human-induced land degradation on terrestrial ecosystems: A case study of karst areas of south China. Environ. Earth Sci., 75, 1127. 
Masoudi M. (2010). Risk Assessment and Remedial Measures of Land Degradation, in Parts of Southern Iran, Lambert Academic Publishing (LAP), Germany, 220.

Masoudi M. (2014). Risk assessment of vegetation degradation using GIS J. Agr. Sci. Tech.-Iran, 16, 1711-1722.

Masoudi M. and Amiri E. (2015). A new model for hazard evaluation of vegetation degradation using DPSIR framework, a case study: Sadra region, Iran, Pol. J. Ecol., 63, 1-9, DOI: 10.3161/15052249PJE2015.63.1.001.

Masoud Masoudi, Parviz Jokar, and Biswajeet Pradhan (2018). A new approach for land degradation and desertification assessment using geospatial techniques. Nat. Hazards Earth Syst. Sci., 18, 1133-1140.

Mendoza G.A., Martins H. (2006). Multi-criteria decision analysis in natural resource management: A critical review of methods and new modelling paradigms. Forest Ecology and Management 230, 1-22.

McCool D.K., Brown L.C., Foster G.R., Mutchler C.K. and Meyer L.D. (1987). Revised slope steepness factor for the Universal Soil Loss Equation. TRANSACTIONS of the ASAE 30(5), 1387-1396.

McCool D.K., George G.O., Freckleton M., Douglas C.L., Jr. and Papendick R.I. (1993). Topographic effect on erosion from crop land in the northwestern wheat region. TRANSACTIONS of the ASAE 36(4), 1067-1071.

Metternicht G., Zinck J.A., Blanco P.D. \& Del Valle H.F. (2010). Remote sensing of land degradation: Experiences from Latin America and the Caribbean. Journal of Environmental Quality, 39(1), 42-61, DOl: 10.2134/jeq2009.0127.

Morgan R.P.C. (1983). The impact of recreation on mountain soils: towards a predictive model for soil erosion. Conference on the ecological impacts of outdoor recreation on mountain areas in Europe and North America, Recreation Ecology Research Group, Ambleside, Cumbria.

Millennium Ecosystem Assessment (MEA 2005). Ecosystems and Human-Being: Desertification Synthesis; World Resources Institute: Washington, DC, USA.

Millward A.A. and Mersey J.E. (1999). Adapting the RUSLE to model soil erosion potential in a mountainous tropical watershed. Catena, 38(2), 109-129.

Nicholson S.E. Tucker C.J., Ba M.B. (1998). Desertification, drought, and surface vegetation: An example from the West African Sahel. Bull. Am. Meteorol. Soc., 79, 815-830.

Naseer Ahmad and Puneeta Pandey (2018). Assessment and monitoring of land degradation using geospatial technology in Bathinda district, Punjab, India. Solid Earth, 9, 75-90, DOl: 10.5194/se-9-75-2018.

Nitheshnirmal S. Ashutosh Bhardwaj, Dineshkumar C. and Abdul Rahaman S. (2019). Prioritization of Erosion Prone Micro-watersheds using Morphometric Analysis coupled with Multi-Criteria Decision Making. Proceedings MDPI, 2nd International Electronic Conference on Geosciences (IECG 2019).

Abdi O.A.,. Glover E.K. and Luukkanen O. (2013). Causes and Impacts of Land Degradation and Desertification: Case Study of the Sudan. International Journal of Agriculture and Forestry 2013, 3(2), 40-51.

Ghorbanzadeh O., Feizizadeh B. and Blaschke T. (2017). Multi-criteria risk evaluation by integrating an analytical network process approach into GIS based sensitivity and uncertainty analyses, Geomatics, Natural Hazards and Risk, DOI: 10.1080/19475705.2017.1413012.

Olena D. (2017). The role of Remote Sensing in land degradation assessments: opportunities and challenges, European Journal of Remote Sensing, 50(1), 601-613, DOI: 10.1080/22797254.2017.1378926.

Pan J.H. and Li T.Y. (2013). Extracting desertification from LANDSAT imagery based on spectral mixture analysis and Albedo- Vegetation feature space, Nat. Hazards, 25, 915-927, DOI: 10.1007/s11069-013-0665-3.

Pankaj K., Wei Liu, Xi Chu, Yue Zhang, Zhihui Li (2019). Integrated water resources management for an inland river basin in China. Watershed Ecology and the Environment 1, 33-38, DOI: 10.1016/j.wsee.2019.10.002.

Prasannakumar V., Vijith H., Abinod S. and Geetha N. (2012). Estimation of soil erosion risk within a small mountainous sub-watershed in Kerala, India, using Revised Universal Soil Loss Equation (RUSLE) and geo-information technology. Geoscience Frontiers, 3(2), $209-215$.

Prince S., Becker-Reshef I. and Rishmawi K. (2009). Detection and mapping of long-term land degradation using local net production scaling: Application to Zimbabwe. Remote Sens. Environ., 113, 1046-1057.

Rahaman S.A., Ajeez S.A., Aruchamy S. and Jegankumar R. (2015). Prioritization of Sub Watershed based on morphometric characteristics using fuzzy analytical hierarchy process and geographical information system - a study of Kallar watershed, Tamil Nadu. International conference on water resources, coastal and ocean. Aquatic Proc. 4, 1322-1330, DOI: 10.1016/j.aqpro.2015.02.172.

Rahaman S.A., Aruchamy S., Balasubramani K. and Jegankumar R. (2017a). Landuse / land cover changes in semi-arid mountain landscape in southern India: a geoinformatics based markov chain approach. Int. Arch. Photo. Remote Sens. Spatial Inf. Sci., Vol XLII-1/W1. 231-237, DOI: 10.5194/isprs-archives-XLII-1-W1-231-2017.

Rahaman S.A. and Aruchamy S. (2017b). Geoinformatics based landslide vulnerable zonation mapping using analytical hierarchy process (AHP), a study of Kallar river sub watershed, Kallar watershed, Bhavani basin, Tamil Nadu. Model. Earth Syst. Environ., 3(41), 13, DOI: 10.1007/s40808-017-0298-8.

Rahaman S., Aruchamy S. and Jegankumar R. (2016). Geospatial Approach for forest cover change and vulnerability analysis through MCE in Kallar watershed, Part of Nilgiri Biosphere Reserve. Geo Eye, 5(2), 40-50.

Rahaman S., Kumar P., Chen R., Meadows M.E. and Singh R.B. (2020). Remote Sensing Assessment of the Impact of Land Use and Land Cover Change on the Environment of Barddhaman District, West Bengal, India. Front. Environ. Sci. 8:127, DOI: 10.3389/fenvs.2020.00127.

Rahaman S.A. and Venkatesh R. (2020). Application of remote sensing and google earth engine for monitoring environmental degradation in the Nilgiri biosphere reserve and its ecosystem of Western Ghats, India. Int. Arch. Photo. Remote Sens. Spatial Inf. Sci., Volume XLIII-B3, 933-940, DOI: 10.5194/isprs-archives-XLIII-B3-2020-933-2020.

Renard K.G and Ferreira V.A. (1993). RUSLE model description and database sensitivity. Journal of Environmental Quality 22(3), $458-466$. Rhoad R., Milauskas G. and Whipple R. (1991). Geometry for enjoyment and challenge. McDougal Littell, Evanston, IL.

Röder A., Udelhoven T., Hill J., del Barrio G. and Tsiourlis G. (2008). Trend analysis of landsat-tm and -etm+ imagery to monitor grazing impact in a rangeland ecosystem in northern greece. Remote Sensing of Environment 112(6), 2863-2875.

Saaty T.L. (1980). The Analytic Hierarchy Process. McGraw-Hill, New York.

Scott S. and Conacher A. (2008). Land degradation and poverty. Geographical Research 46, 1-3.

Sharma A. (2010). Integrating terrain and vegetation indices for identifying potential soil erosion risk area Geo-Spatial Information Science, 13 (3), 201-209. 
Stephanie W., Timo K., Ana Frelih-Larsen., Keighley M F. and Stefanie A. (2018). Report on Implementing SDG target 15.3 on «Land Degradation Neutrality» Ecologic Institut, Berlin. Umweltbundesamt, Germany.

Svenson L. (2005). Socio-economic Indicators for Causes and Consequences of Land degradation. LADA Technical paper, FAO, Rome. Taddese Y. (2001). Land degradation: a challenge to Ethiopia, Environ. Manage., 27, 815-824, DOI: 10.1007/s002670010190.

Temiz F., Bozdag A., Durduran S.S, Gumus M.G. (2017). Monitoring Coastline Change Using Remote Sensing and Gis Technology: A Case Study of Burdur Lake, Turkey. Fresen. Environ. Bull. 26, 7235-7242.

Taguas E.V., Arroyo C., Lora A., Guzmán G., Vanderlinden K. and Gómez J.A. (2015). Exploring the linkage between spontaneous grass cover biodiversity and soil degradation in two olive orchard microcatchments with contrasting environmental and management conditions, SOIL, 1, 651-664, DOI: 10.5194/soil-1-651-2015.

UNCCD (1999). United Nations Convention to Combat Desertification in Those Countries Experiencing Serious Drought and/or Desertification, Particularly in Africa. Text with Annexes. Secretariat of the Convention to Combat Desertification, Bonn.

United Nations General Assembly (2015). Transforming our world: The 2030 agenda for sustainable development. Retrieved from http:// www.un.org/ga/search/view_doc.asp?symbol=A/RES/70/1\&Lang=E

Uzun A., Somuncu M. (2013). Using Remote Sensing Method to Evaluate the Change of the Land Cover/Land Use in Time in Madra Mountain. Balikesir University Journal of Social Sciences Institute.16(30), 1-21.

Van der Knijff J.M., Jones R.J.A. and Montanarella L. (2000). Soil Erosion Risk Assessment in Europe. EUR 19044 EN Office for Official Publications of the European Communities, Luxembourg 34.

Venkatesh R., Abdul Rahaman S., Jegankumar R. and Masilamani P. (2020). Eco-environmental vulnerability zonation in essence of environmental monitoring and management, Int. Arch. Photogramm. Remote Sens. Spatial Inf. Sci., XLIII-B5-2020, 149-155, DOI: 10.5194/ isprs-archives-XLIII-B5-2020-149-2020.

Wessels K., Prince S., Zambatis N., MacFadyen S., Frost P. and van Zyl D. (2006). Relationship between herbaceous biomass and 1 km2 Advanced Very High Resolution Radiometer (AVHRR) NDVI in Kruger National Park, South Africa. Int. J. Remote Sens., 27, 951-973. 186.

Wischmeier W.H. (1974). New developments in estimating water erosion. 29e Meeting Soil Cons. Soc. Amer. Syracuse, New York. 179-

Wischmeier W.H. and Smith D.D. (1978). Predicting Rainfall Erosion Losses: A Guide to Conservation Planning, Agricultural Handbook No. 537, US Department of Agriculture, Washington DC.

Xie H., Zhang Y., Wu Z. and Lv T. (2020). A Bibliometric Analysis on Land Degradation: Current Status, Development, and Future Directions. Land, 9, 28.

Yu C., Liu K., Meng W., Wu Z. and Rishe N. (2002). A methodology for retrieving text documents from multiple databases. IEEE TKDE 14(6), 1347-1361.

Zhou W., Gang C., Zhou F., Li J., Dong X. and Zhao C. (2015). Quantitative assessment of the individual contribution of climate and human factors to desertification in northwest China using net primary productivity as an indicator. Ecol. Indic., 48, 560-569.

Zuazo V.H.D. and Pleguezuelo C.R.R. (2009). Soil-erosion and runoff prevention by plant covers: a review. In Lichtfouse, Eric; et al. Sustainable agriculture. Springer. 785. 


\section{APPENDICES 1}

K Factor (Soil Erodibility): soil erodibility is predicted as a function of soil and soil profile properties like per cent of silt, very fine sand, clay, organic matter $(\mathrm{OM})$ and structure code (s). The regression equation for estimating erodibility factor values from nomograph as suggested by Wischmerier (1974) is equation (4 and 5):

$$
K=\frac{\left[2.1 \times 10^{-4}(12-O M) M^{1.14}+3.25(s-2)+2.5(p-3)\right]}{759.4}
$$

where, $\mathrm{K}=$ Soil erodibility (ton/yr/MJ/mm), OM = percentage Organic Matter, 's' = soil structural code, 'p' is permeability code and ' $\mathrm{M}$ ' is a function of soil primary particle size fractions calculated as follows:

$$
M=(\% \text { silt }+\% \text { Veryfindsand }) \times(100-\% \text { clay })
$$

Soil structure codes (s): very fine granular (1), fine granular (2), medium or coarse granular (3), blocky, platy, prism (4). Soil permeability codes (p): 1- rapid ( > 150mm/hr), 2- moderate to rapid (50-150mm/hr), 3- moderate (15-50 mm/hr), 4- slow to moderate $(5-15 \mathrm{~mm} / \mathrm{hr}), 5$ - slow $(1-5 \mathrm{~mm} / \mathrm{hr})$, and 6- very slow $(<1 \mathrm{~mm} / \mathrm{hr})$.

\section{Slope length Cont}

The slope length factor has often been expressed as (Zingg, 1940):

$$
L^{\prime}=\alpha \lambda^{m}
$$

where $L$ 'is soil loss (mass per unit area per unit time), $\backslash(\mathrm{m})$ is slope length, and a and $m$ are empirical coefficients. Normalizing to a unit plot of length $22.13 \mathrm{~m}$, both the USLE and RUSLE use the equation

The slope length exponent $\mathrm{m}$ can be calculated as following equation (12 \& 13)

$$
\begin{gathered}
m=\beta /(1+\beta) \\
\beta=(\sin \theta / 0.0896) /\left[3.0(\sin \theta)^{0.8}+0.56\right]
\end{gathered}
$$

Were, $\varnothing$ is the slope angle

To generate LS factor, the following methods were adopted. DEM is used as the primary input data sources by which flow direction and flow accumulation can be prepared. This flow accumulation raster is used for the generation of $L$ factor by using following equation (14).

$$
L=(\text { Flowaccumulation } * \text { cellsize } / 22.13)^{m}
$$

The stream network is created by determining a threshold value. Normally for plain areas 2000 is taken as the threshold value. In hilly areas it will be much less and is assigned 750. The following expressions (15) are used in the raster calculator to estimate L factor

$$
\text { Con(("Flow_Acc"< 500), (Power(("Flow_Acc" *12.5/22.13), 0.14)), (Power((500*12.5/22.13), 0.14))) }
$$

For a generation of S factor, slope map is required, both in radians and in percentage. To convert the slope map in degree to radians the following expressions (16) in raster calculator is used.

$$
\text { Slopedegree } * 22 /(7 * 180)
$$

S factor can be calculated according to equation (17) by using the following expression in raster calculator

$$
\begin{aligned}
& \text { Con }((\text { "Slope_per" }<9),((10.8 * \operatorname{Sin}(\text { "Slope_rad") })+0.03) \text {, } \\
& \text { Power ((Sin("Slope_rad") / Sin }(5.143 * 22 /(7 * 180))), 06))
\end{aligned}
$$

